\title{
A Constituição Política do Canadá: instituições e tendências recentes
}

\section{Diogo Luiz Cordeiro Rodrigues}

Mestre em Direito do Estado pela Universidade Federal do Paraná (UFPR), com temporada de pesquisa na Universidade de Toronto. Bacharel em Direito pela Universidade do Estado do Rio de Janeiro (UERJ). Procurador do Estado do Paraná. E-mail:

diogo.luiz.cordeiro@gmail.com

\section{Resumo}

O presente artigo tem por objetivo oferecer ao leitor uma visão crítica da Constituição política do Canadá, cuja nota distintiva é a adoção de um arranjo parlamentarista de matriz britânica, em que se destaca a autoridade do primeiro ministro em detrimento da oposição instalada no Parlamento ou mesmo de outras possíveis instâncias de controle, como entidades burocráticas independentes.

\section{Palavras-chave}

Parlamentarismo canadense, modelo de Westminster, primazia do Primeiro Ministro, relações Executivo-Legislativo, sistemas de governo.

\section{The Political Constitution of Canada: Institutions and Recent Trends}

\footnotetext{
Abstract

This article aims to give the reader a critical overview on the Canadian political Constitution, whose distinctive feature is the adoption of a parliamentary arrangement from British origins, which emphasizes the prime minister's authority over the opposition rooted in Parliament or even over other possible instances of control, as independent bureaucratic entities.

Keywords

Canadian parliamentary system, the Westminster model, primacy of the Prime Minister, Executive-Legislative relations, systems of government.
} 


\section{Sumário}

Introdução. 1. Características gerais. 2. O ordenamento constitucional do Canadá: as fontes. 3. O princípio do governo responsável. 3.1. Linhas gerais. 3.2. Notas históricas. 3.3. Dinâmica atual. 4. O Poder Executivo. 4.1. A chefia de Estado formal: monarca e governador-geral. 4.2. A chefia de Estado política: o Primeiro Ministro e seu gabinete. 5. 0 Poder Legislativo. 5.1. A Câmara dos Comuns. 5.2. O Senado. 5.3. O processo legislativo comum. 6. Os partidos políticos. 7. As agências independentes. 8. Avaliação geral e síntese conclusiva. 9. Referências bibliográficas.

\section{Introdução}

Atualmente, no Brasil, muito se fala sobre a possível adoção do parlamentarismo como via de estabilização do sistema político pátrio, que ora sofre com uma profunda crise entre os Poderes Executivo e Legislativo. Pouco se sabe, no entanto, sobre o efetivo funcionamento das democracias parlamentaristas. Este trabalho é dedicado ao sistema político do Canadá, o único Estado parlamentarista das Américas.

Meu objetivo não é esgotar o tema, que poderia dar origem a diversas obras de fôlego. Ao contrário, pretendo oferecer ao leitor uma visão panorâmica, porém crítica, sobre a constituição política do Canadá, sem descuidar de seus desafios e tendências mais recentes.

Neste trabalho, não darei demasiada atenção ao Poder Judiciário, que costuma monopolizar a atenção dos pesquisadores do Direito Constitucional. Tampouco analisarei o rico e descentralizado federalismo canadense em profundidade. Muito ao contrário, o foco de análise, aqui, será voltado ao que Arend Lijphart denomina "eixo Executivopartidos", que compreende o sistema político-parlamentar e a estrutura partidária ${ }^{1}$. Em acréscimo, cuido da crescente estrutura burocrática do país norte-americano, cujo alcance tem sido objeto de um acalorado debate acadêmico.

Desse modo, almejo não só preencher uma lacuna grave na literatura nacional, como também espero dissipar alguns mitos relacionados ao parlamentarismo, como aquele que coloca a instância legislativa necessariamente em destaque na relação com o Executivo (ou Governo, na nomenclatura aqui adotada). Em verdade, ao menos em sistemas dotados de poucos partidos, é o contrário que costuma ocorrer. No modelo de Westminster adotado no Canadá, por exemplo, o Primeiro Ministro concentra, em si, quase todas as prerrogativas relevantes para a manutenção da dita governabilidade, sem que, em geral, haja contrapartida de poder em igual medida por parte dos órgãos de controle protagonistas e ancilares.

${ }^{1}$ LIJPHART, Arend. Patterns of Democracy. Patterns of democracy: Government forms and performance in thirty-six democracies. New Haven: Yale University Press, 1999, p. 3/4. 
Feitas essas ponderações iniciais, passo a tratar do caso proposto.

\section{Características gerais}

O Canadá é uma monarquia constitucional parlamentar ${ }^{2}$. Membro da Commonwealth, o país tem como atual Chefe de Estado a rainha Elizabeth $\mathrm{II}^{3}$ e seu sistema político, em geral, reflete o legado britânico ${ }^{4}$, à exceção do federalismo incorporado com o intuito de acomodar interesses regionais ${ }^{5}$, em especial os da comunidade pioneira de origem francesa ${ }^{6}$. Em 1982, o advento da Carta de Direitos contribuiu para o reforço do papel desempenhado pela Suprema Corte, principalmente em relação à tutela dos direitos humanos, mas não foi capaz de afetar os caracteres básicos do sistema parlamentarista copiado de Westminster ${ }^{7}$, que continua a ser regido por convenções não escritas imunes à intervenção judiciária e indiferentes à rigidez própria da Constituição escrita ${ }^{8}$.

\section{O ordenamento constitucional do Canadá: as fontes}

Em muitos países, o conjunto de princípios e regras de natureza constitucional deriva de um único documento, geralmente designado por "Constituição". É o caso do Brasil. Embora a doutrina brasileira reconheça a existência de outras fontes de direito constitucional, como costumes não escritos ${ }^{9}$, o fato é que todas as grandes questões acerca do exercício do poder e de seus limites são reconduzidas a certos dispositivos estabelecidos pela Constituição de 1988, ainda que, para tanto, seja necessário algum

\footnotetext{
2 BROOKS, Stephen. Canadian Democracy: An Introduction. 4th ed. Toronto: Oxford University Press - Canada, 2004, p. 219.

${ }^{3}$ Quando a rainha não está presente no Canadá, o que ocorre na maior parte do tempo, seus poderes, hoje substancialmente simbólicos, são exercidos pelo governador-geral (BROOKS, Stephen. Canadian Democracy: An Introduction. 4th ed. Toronto: Oxford University Press - Canada, 2004, p. 131). O papel do governador-geral tem assento no Ato Constitucional de 1867. Nada obstante, o Poder Executivo é efetivamente exercido pelo Primeiro Ministro, como será visto.

${ }^{4}$ Legado expresso já no preâmbulo do Ato Constitucional de 1867, que declara ter o Canadá adotado "a Constitution similar in principle to that of the United Kingdom".

${ }^{5}$ BROOKS, Stephen. Canadian Democracy: An Introduction. 4th ed. Toronto: Oxford University Press - Canada, 2004, p. 124.

${ }^{6}$ MONAHAN, Patrick; SHAW, Byron. Constitutional Law. $4^{\text {th }}$ ed. Toronto: Irwin Law, 2013, p. 14.

7 BROOKS, Stephen. Canadian Democracy: An Introduction. 4th ed. Toronto: Oxford University Press - Canada, 2004, p. 139.

${ }^{8}$ Segundo MONAHAN, Patrick; SHAW, Byron. Constitutional Law. $4^{\text {th }}$ ed. Toronto: Irwin Law, 2013, p. 20.

9 BARROSO, Luís Roberto. Curso de Direito Constitucional Contemporâneo. São Paulo: Saraiva, 2009, p. 48; TAVARES, André Ramos. Curso de Direito Constitucional. 10ạ ed. São Paulo: Saraiva, p. 44. 
grau variável de mediação hermenêutica (afinal, como hoje é notório, "texto" e "norma" não se equivalem $)^{10}$.

No Canadá, o problema das fontes do direito constitucional revela-se muito mais complexo, visto que o povo canadense não dispõe de uma Constituição monolítica para chamar de sua. Do ponto de vista objetivo, o Direito Constitucional canadense é um verdadeiro mosaico de documentos escritos e convenções informais forjadas ao longo da história do país, fortemente marcada por sua relação com a antiga metrópole, o Reino Unido.

Ao contrário do que ocorreu com seu vizinho do sul, os Estados Unidos, a independência política do Canadá em relação ao Reino Unido resultou de um longo, paulatino e consensual processo histórico, não concluído em caráter definitivo até os dias de hoje, pelo menos no plano simbólico. Basta lembrar, como já dito, que o país integra a Commonwealth e tem a rainha Elizabeth como sua Chefe de Estado ${ }^{11}$. Além disso, os atos constitucionais escritos mais relevantes do Canadá são, na verdade, diplomas editados pelo Parlamento britânico, como será visto logo adiante ${ }^{12}$.

Atualmente, o conceito de "Constituição" é dado pela seção 52(2) do Ato Constitucional de 1982 e inclui o seguinte: (i) o Ato Constitucional de 1867 (até então chamado de Ato da América do Norte Britânica); (ii) o Ato do Canadá, inclusive sua segunda parte, que contém o próprio Ato Constitucional de 1982; (iii) um rol de diversos estatutos e normas de dignidade constitucional editados entre 1867 e 1982 e, por fim, (iv) todas as emendas aos diplomas mencionados nos itens anteriores ${ }^{13}$.

Até 1982, o Ato Constitucional de 1867, editado pelo parlamento de Westminster, representava a fonte escrita por excelência do Direito Constitucional canadense. O Ato de 1867 cria o novo Domínio do Canadá, atribuindo-lhe uma “Constituição similar em princípio àquela do Reino Unido", conforme passagem registrada no preâmbulo. A ideia básica do Ato Constitucional de 1867 era disciplinar o funcionamento geral das

\footnotetext{
${ }^{10}$ SARMENTO, Daniel; SOUZA NETO, Cláudio Pereira de. Direito Constitucional - teoria, história e métodos de trabalho. Belo Horizonte: Fórum, 2012, p. 358.

${ }^{11}$ É claro que, como Chefe do Estado canadense, a rainha Elizabeth age na condição de rainha do Canadá, não do Reino Unido. De todo modo, sua figura da rainha é sugestiva da proximidade entre as duas nações.

12 Desde um acordo firmado em 1930 por chefes de governo dos países da Commonwealth, o Parlamento imperial britânico não podia legislar ex officio a respeito de assuntos referentes às antigas colônias ultramarinas. Até 1982, no entanto, era do Reino Unido a prerrogativa de editar atos constitucionais primários e emendas constitucionais, desde que solicitados pelo Estado canadense. Somente por força do Canada Act é que foi abolida a autoridade do parlamento de Westminster sobre o país norte-americano. Cf. HOGG, Peter. Constitutional Law of Canada. Toronto: Carswell, 2014, p. 1-6 e 1-28.

${ }^{13}$ MONAHAN, Patrick; SHAW, Byron. Constitutional Law. $4^{\text {th }}$ ed. Toronto: Irwin Law, 2013, p. 4-6.
} 
instituições canadenses à luz do modelo britânico, mas sem alterar o status colonial da região ${ }^{14}$. De novo, o diploma traz o arranjo federativo, a disciplinar a convivência entre as províncias de Nova Scotia, New Brunswick e Canadá (esta última formada por Ontario, antigo "Alto Canadá" e Québec, outrora "Baixo Canadá"). Além disso, o estatuto prevê regras para a admissão de novas províncias ${ }^{15}$.

O Ato do Canadá, de 1982, também editado pelo Parlamento britânico, compreende, na verdade, duas partes. A parte inicial compõe-se de quatro curtas seções, tendo por objetos centrais promulgar o Ato Constitucional previsto na parte "B" e extinguir a autoridade da Legislatura de Westminster sobre o país norte-americano. O Ato Constitucional, por sua vez, contém a importante Carta de Direitos, garante os direitos dos povos aborígenes, cria um procedimento para emenda dos atos constitucionais e estabelece a supremacia da Constituição escrita. Além disso, como já referido, são declarados constitucionais todos os trinta documentos e resoluções listados no Ato Constitucional, além das futuras emendas apostas a todos os atos de dignidade constitucional ${ }^{16}$.

Nada obstante, o conceito descrito na seção 52(2) do Ato Constitucional de 1982 longe está de encerrar o debate sobre o significado da Constituição canadense, até porque, segundo o próprio dispositivo, o rol apresentado é meramente exemplificativo. Vale ressaltar que o Ato Constitucional de 1982 omite uma série de estatutos relevantes, tais como os editados antes de 1867, que abrangem, por exemplo, as Constituições ainda vigentes de Nova Scotia (1749), Prince Edward Island (1769), New Brunswick (1784), Newfoundland (1832) e British Columbia (1866), além das Letters Patent, de 1947, que constituem o escritório do governador-geral, entre outros diversos estatutos importantes ${ }^{17}$. Além disso, os princípios e regras constitucionais de direito comum, desenvolvidos pelos precedentes judiciais, também constituem importante fonte do Direito Constitucional canadense. Nessa linha, a própria Suprema Corte reconheceu que a noção de "privilégios parlamentares", tal como avançada pela jurisprudência ${ }^{18}$, integra o

${ }^{14}$ Segundo Peter Hogg, "the B.N.A. Act did not mark any break with the colonial past. Independence from the United Kingdom was not desired or even contemplated for the future. The new Dominion, although enjoying a considerable degree of self-government, remained a British colony."Cf. HOGG, Peter. Constitutional Law of Canada. Toronto: Carswell, 2014, p. 1-4.

${ }^{15}$ MONAHAN, Patrick; SHAW, Byron. Constitutional Law. $4^{\text {th }}$ ed. Toronto: Irwin Law, 2013, p. 5. Cf. tb. HOGG, Peter. Constitutional Law of Canada. Toronto: Carswell, 2014, p. 1-3/1.4.

${ }^{16}$ MONAHAN, Patrick; SHAW, Byron. Constitutional Law. $4^{\text {th }}$ ed. Toronto: Irwin Law, 2013, p. 5/6.

17 HOGG, Peter. Constitutional Law of Canada. Toronto: Carswell, 2014, p. 1-10.

${ }^{18} \mathrm{Em}$ síntese apertada, a expressão "privilégios parlamentares" abrange o conjunto de poderes e prerrogativas (ou privilégios) considerados necessários para que uma assembleia legislativa funcione adequadamente, como, por exemplo, a contratação de empregados pelo Senado e pela Câmara dos 
conceito de "Constituição" extraído da seção 52(2) do Ato Constitucional de 1982, porquanto implícita na já mencionada cláusula preambular do Ato Constitucional de 1867, segundo a qual esse estatuto reflete, em princípio, a Constituição do Reino Unido ${ }^{19}$.

Como se não bastasse, o Direito Constitucional canadense é ainda composto de diversas convenções, aqui definidas como regras constitucionais não sindicáveis judicialmente ${ }^{20}$.

Em geral, convenções são regras obrigatórias que decorrem de práticas observadas informalmente desde muito tempo no cenário político, embora sem lastro em documentos constitucionais escritos. De acordo com Hogg, as convenções distinguem-se dos meros usos, que são práticas reiteradas que não se consideram regras obrigatórias (e.g., nomeação do juiz mais antigo para ocupar o cargo vago de presidente da Suprema Corte). Os usos podem eventualmente transformar-se em costumes, adquirindo, assim, 0 caráter de convenções. Em qualquer caso, todavia, entende-se que o Judiciário não pode impor a observância de um uso ou mesmo de uma convenção. Por isso, as consequências da quebra de um uso ou de uma convenção permanecem no plano estritamente político. A única diferença prática entre a violação de um ou de outro diz respeito à maior gravidade associada ao descumprimento da norma convencional. Nada impede, entretanto, que um costume seja transformado em norma escrita por força de lei. Excepcionalmente, ademais, a Suprema Corte pode vir a chancelar uma convenção, transformando-a, na prática, em uma regra constitucional da common law, passível de invocação e proteção em juízo ${ }^{21}$.

Vale ressaltar que, embora muitas convenções decorram de costumes, ou seja, práticas imemoriais não escritas tornadas regras obrigatórias, também há importantes normas convencionais escritas. É o caso das "convenções-acordos", a exemplo daquela constituída em 1930 pelos chefes de Governo dos países da Commonwealth. Nessa oportunidade, diversos Primeiros-ministros pactuaram por escrito que, a partir de então, o Parlamento britânico não mais poderia editar normas ex officio, ou seja, sem qualquer pedido por parte dos países afetados. Convencionou-se, também, que os representantes

Comuns. Nessa linha, cf. HOGG, Peter. Constitutional Law of Canada. Toronto: Carswell, 2014, p. 114.

${ }^{19}$ Segundo Hogg, esse posicionamento da Suprema Corte foi expressamente adotado em New Brunswick Broadcasting Co. v. Nova Scotia - 1993 (cf. HOGG, Peter. Constitutional Law of Canada. Toronto: Carswell, 2014, p. 1-9).

20 V. HOGG, Peter. Constitutional Law of Canada. Toronto: Carswell, 2014, p. 1-28, p. 1-22.1.

${ }^{21}$ É a autorizada opinião de HOGG, Peter. Constitutional Law of Canada. Toronto: Carswell, 2014, p. $1-25 / 1-26 / 1-28$. 
da rainha em tais países (os chamados governadores-gerais) teriam que contar com o apoio dos respectivos Primeiros-ministros ${ }^{22}$.

As convenções merecem especial atenção de minha parte, até porque, como salienta Hogg a respeito do cenário canadense, "o Direito Constitucional é um dos poucos ramos jurídicos em que estatutos editados pelo Parlamento ou pelas Legislaturas provinciais não constituem a principal fonte de direito" ${ }^{23}$. Na verdade, quase todas as práticas relevantes da política do Canadá são ditadas por regras convencionais não escritas, invariavelmente em descompasso com as disposições constitucionais escritas, principalmente aquelas contidas no Ato Constitucional de 1867. De fato, como leciona o autor canadense, o grande papel das convenções é “conformar poderes legais ultrapassados à luz das noções atuais de governo" 24 . É o caso, por exemplo, dos poderes monárquicos. Segundo o Ato Constitucional de 1867, a Coroa ostenta poderes executivos extraordinários. Na realidade, entretanto, a relevância da monarca não costuma ultrapassar a esfera simbólica. Por força de convenção, a chefia de Governo é exercida pelo Primeiro Ministro, cujo cargo sequer está previsto no estatuto constitucional. A prática do governo de gabinete, que orienta a relação entre Governo e Parlamento, tampouco decorre de disposição constitucional escrita ${ }^{25}$.

\section{O princípio do governo responsável}

\subsection{Linhas gerais}

Princípio do governo responsável é o termo utilizado para designar o mecanismo de formação, exercício e manutenção do Governo em sistemas parlamentaristas de matriz britânica, a exemplo daquele vigente no Canadá.

No Canadá, o Poder Executivo tem estrutura dual: formalmente, a Chefe de Estado é a rainha, que raramente visita o país. Por isso, a monarca possui um representante no Canadá, chamado governador-geral, que é a autoridade responsável por praticar, no país, os atos confiados à Coroa, como a sanção real aposta aos projetos de lei aprovados pelas duas casas do Parlamento. Do ponto de vista prático, no entanto, os poderes monárquicos exercidos pelo governador-geral são bastante limitados pelo princípio do governo

\footnotetext{
22 HOGG, Peter. Constitutional Law of Canada. Toronto: Carswell, 2014, p. 1-28.

${ }^{23}$ HOGG, Peter. Constitutional Law of Canada. Toronto: Carswell, 2014, p. 1-2.

${ }^{24}$ HOGG, Peter. Constitutional Law of Canada. Toronto: Carswell, 2014,p.1-29.

${ }^{25}$ As citações diretas e a lição acerca da inexistência de disciplina escrita para a relação entre Governo e Parlamento encontram-se em HOGG, Peter. Constitutional Law of Canada. Toronto: Carswell, 2014p. 1-2 e 1-29 e 1-5, respectivamente.
} 
responsável, do qual decorrem três efeitos políticos diversos, porém interligados: (i) sob o viés da formação do governo, o representante da rainha é obrigado a indicar o parlamentar líder do partido majoritário na Câmara dos Comuns, que passa a exercer a chefia política do Estado sob a alcunha de Primeiro Ministro; (ii) no exercício de suas tarefas, o governador-geral deve seguir as orientações do Primeiro Ministro, o real detentor das ações políticas do governo e (iii) a manutenção do Primeiro Ministro e de seu gabinete no poder pressupõe o apoio da maioria dos membros do Parlamento. Em sentido estrito, a "responsabilidade" a que se refere o princípio refere-se justamente à relação de confiança entre Governo e Assembleia, descrita no item "iii"26.

Alguns ainda traçam uma distinção entre princípio do governo responsável e governo de gabinete. A diferença estaria no grau de participação da rainha ou de seu representante nos negócios políticos. É que o princípio do governo responsável, em si, não implicaria o afastamento total da monarca e do governador-geral dos negócios políticos ordinários. Já no governo de gabinete, a rainha e seu representante são completamente alijados do cotidiano político, limitando-se, em regra, a referendar as decisões tomadas pelo Primeiro Ministro e seus auxiliares no âmbito de um gabinete apartado, ressalvadas hipóteses excepcionais ${ }^{27}$.

\subsection{Notas históricas}

O princípio do governo responsável foi adotado pelas colônias britânicas da América do Norte antes mesmo de se tornarem o domínio federal do Canadá, em 1867, muito em função das rebeliões de 1837, comandadas por Louis-Joseph Papineau, político da província do Baixo Canadá (atual Québec).

Papineau vocalizava os anseios da população francófona por maior autonomia: à época, a Assembleia Legislativa era composta majoritariamente por colonos de origem francesa, mas o governador nomeado pela monarquia inglesa ignorava as lideranças francófonas, indicando para o Conselho Executivo apenas representantes de língua inglesa, em geral empreendedores protestantes baseados em Montreal. Ainda assim, o encarregado britânico não era obrigado a seguir as orientações do Conselho Executivo, preferindo alinhar-se aos comandos provenientes da metrópole ${ }^{28}$.

Após as revoltas de 1837, o Reino Unido nomeou John George Lambton, Earl of Durham, como governador-geral das colônias britânicas da América do Norte. Uma das

26 HOGG, Peter. Constitutional Law of Canada. Toronto: Carswell, 2014, p. 9-2.

27 MONAHAN, Patrick; SHAW, Byron. Constitutional Law. $4^{\text {th }}$ ed. Toronto: Irwin Law, 2013, p. 47.

28 MONAHAN, Patrick; SHAW, Byron. Constitutional Law. $4^{\text {th }}$ ed. Toronto: Irwin Law, 2013, p. 40/41. 
funções de Lord Durham seria confeccionar um relatório com uma sugestão de reforma política para as colônias. Durham sugeriu, entre outras coisas, a unificação das colônias do Alto Canadá, de maioria anglófona, e do Baixo Canadá, de maioria francófona, a fim de que houvesse a assimilação do povo de origem francesa pelo contingente populacional inglês. Mais importante: Durham recomentou fortemente a adoção do princípio do governo responsável em relação às matérias de interesse local. Pela sugestão de Durham, portanto, o império britânico continuaria a ditar das regras de interesse do Reino Unido, mas passaria a seguir as preferências dos parlamentares canadenses quando se tratasse de assuntos próprios da região. Para o governador, somente a adoção parcial do governo responsável poderia aplacar a ira dos colonos insatisfeitos ${ }^{29}$.

Embora tenha incorporado muitas das sugestões de Durham, inclusive a unificação do Alto Canadá com o Baixo Canadá, o Ato da União, editado em 1840, não adotou o princípio do governo responsável, uma vez que a posição do governador-geral ficaria demasiadamente fragilizada. Nada obstante, o Lord Sydenham, primeiro governador-geral das colônias unificadas, começou a mover a política local na direção do governo responsável, nomeando para o Conselho Executivo membros da Assembleia Legislativa. Sydenham, no entanto, guardou para si a maior parte de seus poderes executivos e não admitiu que a manutenção do Conselho Executivo dependesse da confiança da maioria instalada no Parlamento. Como se não bastasse, Sydenham não permitiu o acesso de francófonos ao gabinete, refletindo a política de assimilação sugerida por Lord Durham e seguida pelo Ato da União, de 1840. Charles Bagot, sucessor de Sydenham, aprofundou a prática do governo responsável. Em sua gestão, a parcela francófona passou a ser representada no Conselho Executivo. Além disso, a indicação de Bagot representou a adoção, de facto, do princípio de que o Conselho Executivo precisa gozar da confiança da Assembleia Legislativa. O princípio do governo responsável seria plenamente aceito a partir das eleições britânicas de 1846, que resultaram na alternância de poder na metrópole, com a consequente nomeação de Earl Grey para o Escritório Colonial. Grey recomendou aos governadores de Nova Scotia e Canadá que as decisões de interesse local fossem tomadas com base nas preferências dos detentores da confiança da Assembleia. E assim foi feito: logo no começo de 1848, quando as Assembleias de Nova Scotia e Canadá apresentaram moções de desconfiança contra seus respectivos Conselhos Executivos, não houve outra saída senão a destituição dos gabinetes, seguida de sua troca por membros que gozavam da confiança dos corpos parlamentares. New Brunswick, Prince Edward

${ }^{29}$ MONAHAN, Patrick; SHAW, Byron. Constitutional Law. $4^{\text {th }}$ ed. Toronto: Irwin Law, 2013, p. 42/43. 
Island e Newfoundland, as demais colônias britânicas localizadas no atual Canadá, também passariam a adotar a fórmula do governo responsável nos anos seguintes ${ }^{30}$.

Em 1849, por fim, o governador-geral da antiga província do Canadá, Lord Elgin, completou o ciclo de maturação do governo responsável: deixando de lado suas próprias convicções, Elgin sancionou uma lei que compensava canadenses por danos causados pelas rebeliões de 1837, respeitando, assim, a opinião do Conselho Executivo apoiado pelo Parlamento ${ }^{31}$.

A passagem do governo responsável para o governo de gabinete, porém, seria complementada apenas em meados da década seguinte, quando o gabinete passou a realizar suas sessões sem a presença do governador-geral indicado pela metrópole. A divisão entre anglófonos e francófonos, porém, tornaria o sistema bastante instável. Na colônia unificada do Canadá, a Legislatura passou a ser comandada por uma aliança mista, formada por líderes das comunidades inglesa e francesa, o que parecia mitigar problemas de ordem cultural, linguística e religiosa. No entanto, firmou-se o princípio da dualidade, a significar que o Conselho Executivo deveria gozar da confiança do "Canadá do Leste" (de maioria francesa) e do "Canadá do Oeste" (de maioria inglesa). Além disso, como corolário do princípio da dualidade, surgiu o princípio da "dupla maioria", aplicável às votações de projetos de lei culturalmente sensíveis. Segundo o princípio da dupla maioria, a aprovação de qualquer projeto deveria passar pelo crivo, não só da maioria do Parlamento como um todo, mas também das maiorias setoriais correspondentes às parcelas oriental (francófona) e ocidental (anglógona) da colônia. Não é preciso dizer que os princípios da dualidade e da dupla maioria abreviaram o tempo de vida dos gabinetes. Entre $1841 \mathrm{e}$ 1867 , estima-se que pelo menos dezoito gabinetes tenham se alternado no governo da colônia ${ }^{32}$, um quadro de insegurança assim explicado por David Smith ${ }^{33}$ :

There is no shortage of reasons to explain the failure: the principle of responsible government was new; the political parties on whom the practice depended were raw; the British model was inimitable: between 1841 and 1858, for example, Conservative and Whig prime ministers, in the persons of Peel, Russell, and Parlmerston, took turns on the government benches at Westminster; in Canada opposition

\footnotetext{
30 MONAHAN, Patrick; SHAW, Byron. Constitutional Law. $4^{\text {th }}$ ed. Toronto: Irwin Law, 2013, p. 45.

${ }^{31}$ MONAHAN, Patrick; SHAW, Byron. Constitutional Law. $4^{\text {th }}$ ed. Toronto: Irwin Law, 2013, p. 46.

32 MONAHAN, Patrick; SHAW, Byron. Constitutional Law. $4^{\text {th }}$ ed. Toronto: Irwin Law, 2013, p. 47/48.

${ }_{33} \mathrm{SMITH}$, David. Across the Aisle: Opposition in Canadian Politics. Toronto: University of Toronto Press, 2013, p. 29/30.
} 
had learned to act irresponsibly, because it held 'no hope of office and no means to call governments to account'; and, most of all, the imperative of dualism - composed of language, religion and regions which had revealed itself a conundrum to opposition intent on acting as an alternative government. The two decades after 1848 saw as features of Canadian politics coalitions and double-headed ministries, a peripatetic capital, and procedural innovations such as, on occasion, resort to a double-majority in the adoption of culturally sensitive bills - denominational rights in regard to education a preeminent example. Supporters of coalition government in Parliament in the twenty-first century would be advised to study the period before 1867, when short-lived oppositions were the rule. In the decade and a half before 1867, the lifespan of individual governments declined, while the number of ministries and elections rose. In the sad words of a high school civics text of seventy years ago, then on the curriculum of four western and two Atlantic provinces: 'Political affairs in Canada [in 1860s] were in a very bad way'.

Do ponto de vista formal, o Ato Constitucional de 1867 nada trouxe de novo em relação ao princípio do governo responsável, já que suas regras continuaram a proclamar a supremacia da Coroa, já então superada por convenções informais. Do ponto de vista eminentemente político, no entanto, o Ato Constitucional de 1867 marca o início dos governos unipartidários. Em grande parte, segundo David Smith, essa mudança deve-se ao gênio de John Macdonald, líder Conservador que conduziria o país ao longo de vinte anos (de 1867 a 1873 e de 1878 a 1891, ano de sua morte). Para Smith, Macdonald teria sido o primeiro homem a conseguir unificar diferentes facções políticas em torno de uma bandeira comum, reinando absoluto sobre a oposição, que demoraria ainda alguns anos até compreender que somente unida poderia apresentar-se ao eleitorado como uma força política alternativa e viável, na figura do Partido Liberal ${ }^{34}$. De todo modo, a figura de Macdonald não deve ser superestimada. Havia uma razão institucional para a adoção de gabinetes monopartidários: o término das alianças dualistas era uma exigência da resolução editada na Convenção da Reforma, de 1859, uma das muitas reuniões que

${ }^{34} \mathrm{SMITH}$, David. Across the Aisle: Opposition in Canadian Politics. Toronto: University of Toronto Press, 2013, p. 32-36.

Revista Publicum

Rio de Janeiro, v.2, n. 2, 2016, p. 83-119

http://www.e-publicacoes.uerj.br/index.php/publicum

DOI: 10.12957/publicum.2016.22758 
precederam o advento do Ato Constitucional de $1867^{35}$. Esse Ato Constitucional, como visto, não formalizou o governo de gabinete, mas o seu preâmbulo, ao indicar para o novo país uma "Constituição similar em princípio à do Reino Unido" sinalizou claramente que o antigo dualismo "França-Inglaterra" não mais poderia ser administrado por meio de coalizões governamentais. A partir de então, com a definitiva incorporação do sistema de Westminster, o dualismo passaria a ser acomodado na própria dinâmica do governo partidário: os anglófonos tomaram a liderança do Partido Conservador; os francófonos, a do Partido Liberal ${ }^{36}$. Ou seja, a partilha deu lugar à alternância de poder e cada partido passou a ocupar o gabinete sozinho, reservando ao grêmio adversário o ofício da oposição. Assim, pode-se dizer que, ao menos na dimensão "Executivo-partidos"37, a solução inicial para os conflitos culturais, étnicos e religiosos no Canadá foi a "anglicização" do sistema, não o consensualismo, destinado somente para a forma de Estado, assumidamente federativa.

\subsection{Dinâmica atual}

O processo de escolha do Primeiro Ministro dispensa maiores explicações: o líder do partido com o maior número de cadeiras na Câmara dos Comuns tem o direito de tentar formar um Governo com o apoio da maioria dos parlamentares ${ }^{38}$. Caso tal partido possua mais da metade das cadeiras da Câmara, o Governo será majoritário e não enfrentará muitos obstáculos para aprovação de sua agenda na Legislatura. No entanto, existe a possibilidade de que o Governo seja formado por um partido que não possua a maioria dos assentos da Câmara dos Comuns. Em tal hipótese, o Governo é dito minoritário e passa a necessitar do apoio de algum outro partido nas votações parlamentares. Em geral, o governo mantém-se pelo tempo de duração da legislatura canadense (cinco anos) ou até que perca a confiança da maioria dos parlamentares da Câmara dos Comuns ${ }^{39}$, mas é possível que o Primeiro Ministro convoque eleições antecipadas no momento que

${ }^{35}$ SMITH, David. Across the Aisle: Opposition in Canadian Politics. Toronto: University of Toronto Press, 2013, p. 33. V. tb. HODGINS, Bruce; WRIGHT, Don; HEICK, Welf. Federalism in Canada and Australia: The early years. Wilfrid Laurier Univ. Press, 2010, p. 34.

${ }^{36} \mathrm{SMITH}$, David. Across the Aisle: Opposition in Canadian Politics. Toronto: Universityof Toronto Press, 2013, p. 37.

${ }^{37}$ A expressão, como será visto adiante, foi cunhada por LIJPHART, Arend. Patterns of Democracy. Patterns of democracy: Government forms and performance in thirty-six democracies. New Haven: Yale University Press, 1999, p. 3/4.

${ }^{38}$ BROOKS, Stephen. Canadian Democracy: An Introduction. 4th ed. Toronto: Oxford University Press - Canada, 2004, p. 132.

39 DOCHERTY, David C. Parliament: Making the Case for Relevance. In: BICKERTON, James and GAGNON, Alain-G. Canadian Politics. Toronto: University of Toronto Press, 6th ed., 2014, p. 154.

Revista Publicum

Rio de Janeiro, v.2, n. 2, 2016, p. 83-119

http://www.e-publicacoes.uerj.br/index.php/publicum

DOI: $10.12957 /$ publicum.2016.22758 
considerar mais oportuno (snapelections) ${ }^{40}$. A confiança é perdida quando o Governo sofre derrota em alguma votação importante (como a do orçamento anual) ou quando uma moção de desconfiança proposta pela oposição é aceita. Neste caso, a tradição demanda que o Primeiro Ministro e seu gabinete abdiquem do poder (decorrência do princípio do governo responsável) ${ }^{41}$. De qualquer forma, mesmo quando perde a confiança do Parlamento, o Primeiro Ministro pode requerer novas eleições ao governador-geral, dissolvendo o Parlamento. Teoricamente, o governador-geral também poderia negar o requerimento do Primeiro Ministro, a fim de conceder a outro líder partidário a oportunidade de tentar estabelecer um Governo com a maioria dos parlamentares eleitos, sem a realização do certame eleitoral. Isso é admissível, por exemplo, quando o Governo derrubado não passou mais do que poucos meses no poder. Em tal hipótese, entende-se que o governador-geral, no exercício de seus poderes residuais, pode oferecer o Governo diretamente a outro líder partidário, a fim de poupar a nação de mais um desgastante processo eleitoral ${ }^{42}$.

Atualmente, tanto a ideia clássica de governo responsável quanto a participação do governador-geral no processo eleitoral cedem passo ao progressivo incremento do poder exercido pelo Primeiro Ministro.

O princípio do governo responsável é reavaliado através das lentes da política partidária. Em sua versão clássica (ou ideal, para alguns), o princípio do governo responsável sugere uma espécie de submissão do Executivo ao Legislativo, que teria a prerrogativa de formar ou derrubar governos. De fato, conforme narrado anteriormente, o Parlamento parece ter preponderado ao longo da fase imediatamente anterior ao advento do Ato Constitucional de 1867. Todavia, não é o que ocorre nos dias de hoje e isso se deve, em boa parte, à extrema disciplina partidária canadense ${ }^{43}$. Em outras

${ }^{40}$ RUSSELL, Peter. Learning to Live with Minority Parliaments. In: RUSSELL, P. and SOSSIN, L. (eds.). Parliamentary Democracy in Crisis. Toronto: University of Toronto Press, 2009, p. 136-149, p. 138.

${ }^{41}$ BROOKS, Stephen. Canadian Democracy: An Introduction. 4th ed. Toronto: Oxford University Press - Canada, 2004, p. 132.

42 Geralmente, entende-se que o governador-geral pode lançar mão dessa prerrogativa quando o Governo não tenha durado mais do que seis meses. Cf. LEVY, Gary. A Crisis Not Made in a Day. In: RUSSELL, P. and SOSSIN, L. (eds.). Parliamentary Democracy in Crisis. Toronto: University of Toronto Press, 2009, p. 19/20.

${ }^{43}$ Brooks comenta que a disciplina partidária canadense é superior à britânica (BROOKS, Stephen. Canadian Democracy: An Introduction. 4th ed. Toronto: Oxford University Press - Canada, 2004, p. 132). Já Docherty explica o porquê: ao contrário do parlamentarismo britânico, em que se confere aos parlamentares a possibilidade de divergência em matérias menos importantes, no parlamentarismo canadense todas as matérias são sujeitas à disciplina partidária e consideradas "de confiança". Cf. DOCHERTY, David C. Parliament: Making the Case for Relevance. In: BICKERTON, James and GAGNON, Alain-G. Canadian Politics. Toronto: University of Toronto Press, 6th ed., 2014, p. 170. A maior disciplina partidária canadense talvez seja explicada pela recorrência dos governos minoritários, que são relativamente raros no Reino Unido. 
palavras: por razões diversas, espera-se que todos os parlamentares pertencentes a um mesmo partido votem como um bloco unificado na legislatura ${ }^{44}$. Se o governo é majoritário, o Primeiro Ministro pode garantir suas vitórias apenas com os votos dos membros de seu partido. A estabilidade é menor para governos minoritários, que dependem do suporte de outro partido para governar. Mesmo aqui, no entanto, a disciplina partidária garante que o governo não precise negociar apoio com cada um dos parlamentares aliados a cada votação importante. A história recente também demonstra que mesmo um Primeiro Ministro minoritário e já sem o apoio das demais agremiações (isto é, sem a confiança da maioria dos legisladores) pode, ainda assim evitar uma moção de desconfiança, mediante fechamento temporário do Parlamento (prorogation). De fato, foi o que Stephen Harper conseguiu fazer em 2008 com o auxílio do governador-geral ${ }^{45}$. Vale ressaltar, ademais, que o Canadá adota o mesmo sistema eleitoral do Reino Unido, o first-past-the-post, cujo efeito principal é reduzir o número de agremiações partidárias numericamente relevantes na arena parlamentar ${ }^{46}$. Nesse contexto, em regra, os governos canadenses conseguem alcançar um grau invejável de estabilidade ${ }^{47}$ e 0 princípio do governo responsável passa a ser compreendido como um dever geral de prestação de contas ao Legislativo ${ }^{48}$.

\section{O Poder Executivo}

Como é notório, o sistema parlamentarista de Westminster é caracterizado pelo fato de que o Governo é um departamento da Assembleia, muito embora, na prática, haja uma dissociação funcional entre as duas esferas, inclusive com predomínio da instância executiva. Assim, do ponto de vista político, o exame do Poder Executivo como ente próprio não é nonsense, como poderiam acreditar os leitores menos informados. Vejamos como o Poder Executivo está organizado no Canadá.

${ }^{44}$ BROOKS, Stephen. Canadian Democracy: An Introduction. 4th ed. Toronto: Oxford University Press

- Canada, 2004, p. 132.

45 DOCHERTY, David C. Parliament: Making the Case for Relevance. In: BICKERTON, James and GAGNON, Alain-G. Canadian Politics. Toronto: University of Toronto Press, 6th ed., 2014, p. 155. ${ }^{46} \mathrm{O}$ sistema eleitoral será objeto de considerações quando o Governo Harper for examinado.

47 De acordo com Brooks, entre 1867 e 2000, apenas 5 dos 37 governos caíram por derrotas em votações na Câmara dos Comuns. Todos minoritários. Mesmo assim, todos os Primeiros Ministros puderam convocar novas eleições, exceto o PM Mackenzie King em 1926.

48 Quando se trata da accountability exercida individualmente sobre os ministérios, fala-se de um princípio da responsabilidade ministerial. Cf. BROOKS, Stephen. Canadian Democracy: An Introduction. 4th ed. Toronto: Oxford University Press - Canada, 2004, p. 133. 


\subsection{A chefia de Estado formal: rainha e governador-geral}

Conforme já salientado, o Canadá é uma monarquia constitucional. Sendo assim, o Governo deve ser conduzido em nome da rainha, que é a Chefe de Estado, ao menos sob o prisma formal. De acordo com o Ato Constitucional de 1867, preservado pelo Ato Constitucional de 1982, o monarca do Canadá será a pessoa investida do mesmo cargo no Reino Unido. O Canadá reconhece, portanto, as regras de sucessão hereditária aplicadas na Grã-Bretanha ${ }^{49}$.

No Canadá, desde as Letters Patent de 1947, praticamente todos os poderes monárquicos são exercidos por seu representante no país, o governador-geral, salvo, é claro, o poder de nomear e exonerar o próprio governador-geral, que permanece com a rainha. De todo modo, já se tornou lugar comum dizer que esses poderes são quase que inteiramente simbólicos e cerimoniais, porquanto operados, na prática, pelo Primeiro Ministro e seus auxiliares.

Recentemente, no entanto, tem-se destacado a relevância de alguns poderes residuais (reserve powers) ou prerrogativas pessoais (personal prerogatives) detidos pela soberana e delegados ao seu representante, para que sejam exercidos em ocasiões excepcionais, em desacordo até mesmo com a opinião do Primeiro Ministro, se necessário for. Para os defensores dessa tese, o governador-geral é a pessoa mais apta para arbitrar crises políticas agudas no cenário canadense, já que não participa dos desgastantes embates partidários travados no âmbito das instâncias representativas. O governadorgeral, dada sua neutralidade política, exerceria uma espécie de Poder Moderador em momentos de grave instabilidade política, tendo por vetor de atuação o interesse do país como um todo, não o de certos partidos políticos ${ }^{50}$. Na mesma linha, alguns defendem que o governador-geral não está obrigado a seguir uma decisão ministerial que lhe pareça frontalmente contrária à Constituição ${ }^{51}$. Esses poderes residuais têm sido objeto de intensas polêmicas nos meios acadêmico e político do Canadá, especialmente porque, nos últimos anos, o Governo Harper pôs à prova o papel moderador da figura do governadorgeral em diversas ocasiões.

\subsection{A chefia de Estado formal: rainha e governador-geral}

${ }^{49}$ HOGG, Peter. Constitutional Law of Canada. Toronto: Carswell, 2014, p. 9-7.

50 HOGG, Peter. Constitutional Law of Canada. Toronto: Carswell, 2014, p. 9-25.

${ }^{51} \mathrm{O}$ debate é relatado por MONAHAN, Patrick; SHAW, Byron. Constitutional Law. $4^{\text {th }}$ ed. Toronto: Irwin Law, 2013, p. 78-81. 
Conforme já destacado, a figura do Primeiro Ministro e a instituição do gabinete não possuem lastro na Constituição escrita do Canadá. O que o Ato Constitucional de 1867 prevê é o chamado Conselho Privado (Privy Council), o corpo consultivo oficial do governador-geral. O Conselho Privado não se confunde com o gabinete ministerial e hoje, para alguns, possui relevância meramente honorífica. Dele fazem parte todos os antigos Primeiros-Ministros, o presidente da Suprema Corte, governadores-gerais aposentados, entre outros cidadãos e autoridades reconhecidos por bons serviços prestados ao país ${ }^{52}$.

Já o gabinete, consiste no corpo ministerial responsável por exercer o Governo sob a liderança do Primeiro Ministro. Formalmente, compete ao governador-geral indicar tanto o Primeiro Ministro quanto os demais membros do gabinete, mas o representante da rainha não possui discricionariedade na escolha. O Primeiro Ministro é necessariamente o líder do partido majoritário na Câmara dos Comuns e ele próprio indica os parlamentares que integrarão o gabinete ${ }^{53}$. No Canadá, o gabinete é majoritariamente formado por parlamentares da Câmara dos Comuns, mas pode conter um ou dois senadores, a fim de que sejam representadas na instância executiva aquelas localidades nas quais o partido governista não tenha conseguido eleger um grande número de representantes ${ }^{54}$. Todavia, tal medida costuma causar polêmica, uma vez que o Senado não integra o pool de instituições e princípios democrático-representativos do Canadá: o governo não depende do suporte do Senado para se manter no poder (ou seja, a Câmara Alta não é uma "casa de confiança"), os senadores não são democraticamente eleitos e, por fim, mesmo quando investidos da função de Ministro, não podem prestar contas sobre seu ministério à Câmara dos Comuns ${ }^{55}$. Sendo assim, quando indicado para uma Pasta do gabinete, espera-se que o Ministro-senador imediatamente abdique do cargo vitalício no Senado e concorra a um mandato popular pela Câmara dos Comuns ${ }^{56}$. Também é importante reiterar que os membros do gabinete invariavelmente pertencem ao partido do primeiro ministro. Nesse particular, o Canadá segue rigorosamente os preceitos do modelo de Westminster, contrário a governos de coalizão ${ }^{57}$. Essa predileção, como visto, deita raízes no Ato Constitucional de 1867, que representou uma virada em

52 MONAHAN, Patrick; SHAW, Byron. Constitutional Law. $4^{\text {th }}$ ed. Toronto: Irwin Law, 2013, p. 63.

53 MONAHAN, Patrick; SHAW, Byron. Constitutional Law. $4^{\text {th }}$ ed. Toronto: Irwin Law, 2013, p. 64.

${ }^{54}$ BROOKS, Stephen. Canadian Democracy: An Introduction. 4th ed. Toronto: Oxford University Press

- Canada, 2004,p. 221.

55 HOGG, Peter. Constitutional Law of Canada. Toronto: Carswell, 2014, p. 9-14.

${ }^{56}$ Foi o que aconteceu em 2006, quando Harper nomeou o senador Michael Fortier para o posto de Ministro dos Trabalhos Públicos. No entanto, Fortier não conseguiu ser eleito no distrito escolhido. Cf. MONAHAN, Patrick; SHAW, Byron. Constitutional Law. $4^{\text {th }}$ ed. Toronto: Irwin Law, 2013, p. 65.

${ }^{57}$ Não se deve olvidar, todavia, que o próprio Reino Unido afastou-se desse princípio clássico de Westminster em 2010, quando o gabinete passou a ser ocupado pelo governo de coalizão formado por Conservadores e Liberais Democratas. 
relação ao período anterior, quando o dualismo "França-Inglaterra" dificultava sobremaneira os assuntos governamentais.

Classicamente, diz-se que não há hierarquia entre os ministros, mas a prática tem demonstrado que o Primeiro Ministro é, de fato, o ator mais forte do Poder Executivo canadense, até porque são dele, entre outras, as prerrogativas de nomear e exonerar seus colegas, hoje considerados meros auxiliares. Na verdade, segundo Donald Savoie, um arguto observador da cena política do Canadá, o gabinete já nem representa a instância deliberativa principal do Poder Executivo, já que o Primeiro Ministro prefere tomar suas decisões no âmbito do Prime Minister's Office (PMO) e do reabilitado Privy Council Office (PCO), com o auxílio de assessores de sua confiança e dois ou três ministros-chave (o gabinete completo chega a ultrapassar trinta membros). Trata-se do que o autor denomina "governo de corte" (court government) $)^{58}$.

Savoie ancora seu argumento em diversos exemplos concretos. Alguns simplesmente revelam o exercício unilateral do poder pelo Primeiro Ministro ${ }^{59}$. Outros, porém, evidenciam mudanças políticas mais profundas. Uma delas diz respeito ao surgimento de uma espécie de federalismo executivo, pelo qual Primeiro Ministro e Premiers provinciais firmam acordos diretos em Ottawa, sem consulta prévia a Gabinetes ou Parlamentos. Invariavelmente, o Primeiro Ministro designa algum departamento burocrático para supervisionar a implementação do acordo ${ }^{60}$.

Outra relevante mudança diz respeito ao orçamento público. Segundo Savoie, todas as decisões relevantes acerca da alocação de recursos são tomadas pelo Primeiro Ministro e um punhado de indivíduos (notadamente, o Ministro da Finança e o Presidente do Tesouro). A razão é simples: austeridade fiscal. No sistema antigo, quando as propostas de gastos eram definidas no âmbito de cada Pasta ministerial, os titulares simplesmente não conseguiam rejeitar propostas apresentadas por colegas

58 SAVOIE, Donald J. Power at the Apex: Executive Dominance. In: BICKERTON, James and GAGNON, Alain-G. Canadian Politics. Toronto: University of Toronto Press, 6 th ed., 2014, p. 135.

59 Eis um deles: "Senator Lowell Murray, a highly respected minister in the Mulroney Cabinet, maintains that cabinet government now is dysfunctional. How could it not be, given that the key decisions regarding Canada's military deployments in Afghanistan (one by a Liberal government and another by a Conservative government) were made by the prime minister with the help of only a handful of political advisors and civilian and military officials? The two relevant ministers - of National Defense and Foreign Affairs - were not even in the room. They, like Cabinet, were informed after the fact (Murray, 2013)." SAVOIE, Donald J. Power at the Apex: Executive Dominance. In: BICKERTON, James and GAGNON, Alain-G. Canadian Politics. Toronto: University of Toronto Press, 6 th ed., 2014, p. 136.

60 SAVOIE, Donald J. Power at the Apex: Executive Dominance. In: BICKERTON, James and GAGNON, Alain-G. Canadian Politics. Toronto: University of Toronto Press, 6 th ed., 2014, p. 136/141.

Revista Publicum

Rio de Janeiro, v.2, n. 2, 2016, p. 83-119

http://www.e-publicacoes.uerj.br/index.php/publicum

DOI: 10.12957/publicum.2016.22758 
parlamentares, ao mesmo tempo em que também não eliminavam sua própria fatia do orçamento $^{61}$.

Algumas tendências do mundo contemporâneo também ajudam a explicar o fortalecimento do Primeiro Ministro. Antes, os conselhos dos ministros integrantes do gabinete eram essenciais para que o governante tomasse ciência das preferências populares nas províncias, por exemplo. Reinava, portanto, um estado de assimetria de informações entre Primeiro Ministro e auxiliares, estes geralmente mais próximos das bases regionais. Hoje, no entanto, o Primeiro Ministro pode simplesmente confrontar seus auxiliares com pesquisas de opinião profissionais. ${ }^{62}$

De acordo com Savoie, o fenômeno da globalização também contribuiu para a hipertrofia do Primeiro Ministro. Atualmente, muitas decisões são efetivamente tomadas em fóruns internacionais, como G8 e la Francophonie. Todavia, enquanto o Presidente americano precisa entender-se com o Congresso, o Primeiro Ministro canadense tem poderes para assumir acordos diretamente. Assim como no cenário doméstico, o que vem a seguir é o anúncio da decisão e um esforço dos auxiliares para cumpri-la. Um dos resultados mais evidentes da força ostentada pelo Primeiro Ministro canadense é já o habitual bypass do gabinete ${ }^{63}$.

Embora o Primeiro Ministro possua clara ascendência sobre os assuntos do Governo, é possível que, vez ou outra, o governador-geral (mas não os ministros) possua boas razões para não seguir suas diretrizes. Isso ocorre, por exemplo, quando o Primeiro Ministro e seu gabinete são derrubados por um voto de desconfiança da Câmara dos Comuns. Afinal, por convenção, o governador-geral é obrigado a seguir o conselho do Primeiro Ministro apenas enquanto este possua a confiança da maioria instalada na Câmara. Como já foi dito na seção dedicada à dinâmica atual do princípio do governo responsável, é legítimo que o governador-geral recuse a solicitação de novas eleições por parte de um Primeiro Ministro derrotado, quando o último certame eleitoral tenha ocorrido poucos meses antes. Nada obstante, trata-se de uma circunstância absolutamente excepcional: a última recusa ocorreu em 1926, no famoso caso “KingByng"64.

${ }^{61}$ SAVOIE, Donald J. Power at the Apex: Executive Dominance. In: BICKERTON, James and GAGNON, Alain-G. Canadian Politics. Toronto: University of Toronto Press, 6 th ed., 2014, p. 137.

62 SAVOIE, Donald J. Power at the Apex: Executive Dominance. In: BICKERTON, James and GAGNON, Alain-G. Canadian Politics. Toronto: University of Toronto Press, 6 th ed., 2014, p. 140/141.

${ }^{63}$ SAVOIE, Donald J. Power at the Apex: Executive Dominance. In: BICKERTON, James and GAGNON, Alain-G. Canadian Politics. Toronto: University of Toronto Press, 6 th ed., 2014, p. 143-148.

${ }^{64}$ No caso, o então governador-geral, Lord Byng, recusou o pedido do primeiro ministro Mckenzie King para dissolver o Parlamento, pois, na opinião do mandatário da rainha, o líder do Partido Liberal já não possuiria a confiança da maioria parlamentar, mesmo que ainda houvesse nenhum 


\section{O Poder Legislativo}

De acordo com a seção 17 do Ato Constitucional de 1867, o Poder Legislativo é composto pela rainha, pela Câmara Alta (denominada Senado) e pela Câmara dos Comuns. Ao menos formalmente, portanto, a aprovação de projetos de lei requer a conjunção dessas três vontades. Na prática, como já visto, o gabinete geralmente é poderoso o bastante para controlar o processo legislativo ${ }^{65}$.

\subsection{A Câmara dos Comuns}

A Câmara dos Comuns é o corpo representativo por excelência do Parlamentarismo canadense, já que seus membros são os únicos eleitos pelo sufrágio direto e universal. Em regra, sua importância é eclipsada, visto que a política partidária tende a fazer da Câmara Baixa uma simples correia de transmissão das decisões emanadas do Primeiro Ministro, conforme amplamente demonstrado neste trabalho. Não por outro motivo, o ápice da carreira parlamentar é a passagem para o gabinete. Aos parlamentares do partido governista sem qualquer função no gabinete (os chamados backbenchers ${ }^{66}$ ), resta apenas seguir fielmente as diretrizes de seu partido nas votações plenárias. O esforço das comissões parlamentares é destituído de efeito prático ${ }^{67}$ e boa parte dos backbenchers afirma que a parte mais gratificante de seu trabalho é a ajuda direta aos eleitores de seu distrito ${ }^{68}$. Bem por isso, são frequentes os anseios populares por reformas, a fim de que os parlamentares individuais tenham mais poder e possam, de fato, contrastar as políticas gestadas no seio do governo. Geralmente, essas propostas advogam a adoção do sistema de representação proporcional (que aumentaria o número de partidos políticos relevantes na Câmara dos Comuns, dificultando a centralização do processo decisório) ou o fortalecimento da burocracia parlamentar externa ao gabinete.

voto de não confiança contra King. O incidente seria reavivado entre 2008 e 2009, com o primeiro "prorogation" solicitado por Harper. Sobre o "caso King-Byng", v. MONAHAN, Patrick; SHAW, Byron. Constitutional Law. $4^{\text {th }}$ ed. Toronto: Irwin Law, 2013, p. 72-74. Já sobre a crise do prorogation ocorrida no governo Harper, cf. os textos contidos em RUSSELL, P. and SOSSIN, L. (eds.). Parliamentary Democracy in Crisis. Toronto: University of Toronto Press, 2009.

65 HOGG, Peter. Constitutional Law of Canada. Toronto: Carswell, 2014, p. 9-15.

${ }^{66} \mathrm{~A}$ expressão abrange também os parlamentares oposicionistas que não ocupam posições de liderança. Em comum, todo esse "baixo clero" senta-se nos bancos ao fundo, logo atrás dos primeiros bancos, que são destinados aos líderes. Daí porque são chamados de "backbenchers". Nesse sentido, cf. MCMENEMY, John. The Language of Canadian Politics - a guide to important terms \& concepts. $4^{\text {th }}$ ed. Wilfrid Laurier University Press, 2006, p. 10.

${ }^{67}$ BROOKS, Stephen. Canadian Democracy: An Introduction. 4th ed. Toronto: Oxford University Press - Canada, 2004, p. 243.

${ }^{68}$ DOCHERTY, David C. Parliament: Making the Case for Relevance. In: BICKERTON, James and GAGNON, Alain-G. Canadian Politics. Toronto: University of Toronto Press, 6th ed., 2014, p. 163/164. 
De qualquer sorte, não se pode esquecer que a Câmara dos Comuns é o local em que se instala a oposição formada pelos partidos excluídos do governo. Muito embora haja uma tendência do Primeiro Ministro de apelar diretamente à opinião pública e à imprensa, o fato é que remanesce, no Canadá, o ritual de confronto entre Governo e Oposição na arena parlamentar.

O confronto político em sistemas parlamentares à moda de Westminster obedece a uma lógica binária e adversarial: o maior partido não governista recebe da Coroa o título de "Oposição Oficial", com direito inclusive a gabinete próprio nas dependências do Parlamento. À “Oposição Oficial” não cabe qualquer papel na administração dos negócios públicos. Sua tarefa é criticar as ações do Primeiro Ministro e de seu gabinete, apresentando-se aos eleitores como alternativa viável para o certame eleitoral seguinte. É a oposição política em estado puro ${ }^{69}$, exercida regularmente durante os chamados question periods e opposition days, oportunidades em que os Ministros do gabinete são obrigados a prestar contas de suas atividades perante os membros do Parlamento ${ }^{70}$. Para o bem ou para o mal, no entanto, o governo detém a prerrogativa de controlar a agenda dos dias da oposição ${ }^{71}$.

Em períodos de governos majoritários, o exercício da oposição pode revelar-se extremamente frustrante: limita-se a registrar críticas e apontar falhas, muitas vezes em tom bastante áspero, mas sem qualquer efeito prático do ponto de vista decisório ${ }^{72}$. Todavia, governos minoritários tendem a não ser tão dominantes, já que o cenário partidário torna-se mais balanceado: enquanto o governo é conduzido por um partido, o Parlamento é dominado pela oposição oficial e pelas demais agremiações políticas. 0 Canadá, ao contrário do Reino Unido, tende a gerar governos minoritários com alguma frequência ${ }^{73}$, talvez porque o sistema eleitoral first-part-the-post não consiga neutralizar inteiramente as fortes clivagens culturais e regionais do país, que se refletem nos chamados third parties, ou seja, partidos menores, em geral dedicados à representação de interesses regionais específicos, como será visto a seguir.

69 HELMS, Ludger. Five ways of institutionalizing political opposition: lessons from the advanced democracies. Government and Opposition, v. 39, n. 1, 2004, p. 22-54.

70 BROOKS, Stephen. Canadian Democracy: An Introduction. 4th ed. Toronto: Oxford University Press

- Canada, 2004,p. 242/243.

71 MONAHAN, Patrick; SHAW, Byron. Constitutional Law. $4^{\text {th }}$ ed. Toronto: Irwin Law, 2013, p. 103.

72 MÖLLERS, Christoph. The Three Branches - A Comparative Model of Separation of Powers. Oxford: Oxford University Press, 2013, p. 85.

$73 \mathrm{O}$ ponto é salientado por KAISER, Andre. Parliamentary Opposition in Westminster Democracies: Britain, Canada, Australia and New Zealand. The Journal of Legislative Studies, v. 14, n. 1-2, 2008, p. 23.

Revista Publicum

Rio de Janeiro, v.2, n. 2, 2016, p. 83-119

http://www.e-publicacoes.uerj.br/index.php/publicum

DOI: 10.12957/publicum.2016.22758 
Dois exemplos demonstram claramente o contraste entre governos minoritários e majoritários no cenário canadense. Veja-se a função de Presidente da Câmara (Speaker of the House). Trata-se de uma autoridade essencial na direção dos trabalhos parlamentares. Até 1986, o Presidente da Câmara era indicado pelo primeiro ministro sem oposição. Hoje, a escolha do Presidente é feita por eleição secreta entre os parlamentares. É claro que, em governos majoritários, o voto secreto não constitui empecilho de monta. Em períodos de governo minoritário, contudo, é provável que a oposição trabalhe para eleger um Presidente aliado. Até 2011, por exemplo, quando o governo Conservador de Harper possuía status minoritário, a Presidência da Casa era ocupada pelo Liberal Peter Milliken. Contudo, logo após a conquista do status majoritário, em maio de 2011, a Presidência da Casa passou a ser ocupada pelo Conservador Andrew Sheer, decerto com o apoio da nova maioria $^{74}$.

Outro exemplo interessante é o da distribuição de assentos na Câmara dos Comuns. Em regra, a representação na Câmara Baixa é proporcional à população dos distritos, conforme o censo decenal (Ato Constitucional de 1867, seção 51). Ou seja, quanto mais populoso um distrito, maior a quantidade de representantes no Parlamento. Essa regra, porém, está sujeita a uma série de mitigações em prol da representatividade das províncias menos populosas. A seção $51 \mathrm{~A}$, por exemplo, assegura a cada província um número de assentos nunca inferior ao que possua no Senado. Com isso, províncias diminutas como Prince Edward Island e New Brunswick têm direito a pelo menos 4 (quatro) representantes na Câmara dos Comuns, muito embora, pelo mero critério proporcional, esse número não seja justificável. Além disso, o cálculo proporcional não pode resultar em um número de representantes inferior àquele detido pelas províncias por ocasião do Ato Constitucional de 1985. Desse modo, províncias como Québec continuam a manter um número estável de representantes na Câmara dos Comuns, a despeito de seu decréscimo populacional ${ }^{75}$. Isso obviamente dificultaria a governabilidade de um governo Conservador, como o de Stephen Harper, cuja base eleitoral assenta sobre as populosas, porém tradicionalmente sub-representadas, províncias do oeste anglófono. Tanto é assim que uma das primeiras providências do governo majoritário de Harper, em 2011, foi a aprovação do Fair Representation Act, na verdade uma emenda à seção 51 do Ato Constitucional de 1867, contendo uma nova fórmula que, na prática, resultou em

74 MONAHAN, Patrick; SHAW, Byron. Constitutional Law. $4^{\text {th }}$ ed. Toronto: Irwin Law, 2013, p. 93/94.

75 MONAHAN, Patrick; SHAW, Byron. Constitutional Law. $4^{\text {th }}$ ed. Toronto: Irwin Law, 2013, p. 92/93.

Revista Publicum

Rio de Janeiro, v.2, n. 2, 2016, p. 83-119

http://www.e-publicacoes.uerj.br/index.php/publicum

DOI: $10.12957 /$ publicum.2016.22758 
cadeiras adicionais para as províncias de Ontario (15 cadeiras), Alberta (6 cadeiras) e British Columbia ( 6 cadeiras $)^{76}$.

\subsection{O Senado}

O Senado é a Câmara Alta do Parlamento do Canadá e dispõe, ao menos formalmente, dos mesmos poderes da Câmara dos Comuns no processo legislativo, exceto no que diz respeito aos money bills (projetos de lei sobre receitas e despesas), que devem propostos a partir da Câmara Baixa. Assim como instituições congêneres encontradas em outros Estados federais, sua função básica seria proteger interesses regionais no plano da política nacional. Seus membros são formalmente nomeados pelo governador-geral, porém, na prática, é o Primeiro Ministro que os indica. Os senadores podem manter seus cargos até os 75 anos de idade ${ }^{77}$.

Hoje está claro que o Senado não cumpre adequadamente sua tarefa de representação dos interesses regionais no Parlamento. Isso porque as províncias não possuem qualquer papel na escolha dos senadores, que são indicados pelo Primeiro

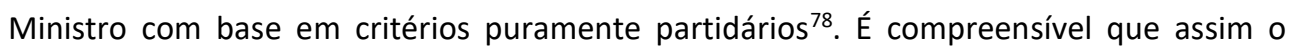
seja: porque detém os mesmos poderes atribuídos pela Constituição à Câmara dos Comuns, um Senado composto por adversários políticos do Primeiro Ministro certamente abalaria a eficiência do governo, convertendo-se em um ator com poder de veto.

No entanto, a falta de lastro democrático faz com que o Senado raramente crie embaraços ao governo, mesmo quando composto majoritariamente de membros de partidos oposicionistas, indicados por governos anteriores. Nada obstante, essa prática pode eventualmente ser quebrada. O governo Progressista-Conservador eleito em 1984, por exemplo, costumava enfrentar a resistência de um Senado então dominado por membros indicados pelos Liberais, que haviam permanecido no poder por longos anos. Isso não impediu, contudo, que o então Primeiro Ministro Brian Mulroney, com base na seção 26 do Ato Constitucional de 1867, acrescentasse 8 (oito) assentos temporários ao Senado com o objetivo de superar a oposição da maioria Liberal à criação do imposto sobre bens e serviços (Goodsand Services Tax) ${ }^{79}$.

${ }^{76}$ Sobre o Fair RepresentationAct, conferir a seguinte página virtual do governo canadense: <http://www.democraticreform.gc.ca/eng/content/fair-representation-act-moves-every-provincetowards-rep-pop> Acesso em 24/01/2015.

77 HOGG, Peter. Constitutional Law of Canada. Toronto: Carswell, 2014, p. 9-17/18.

78 HOGG, Peter. Constitutional Law of Canada. Toronto: Carswell, 2014, p. 9-17/18.

${ }^{79}$ BROOKS, Stephen. Canadian Democracy: An Introduction. 4th ed. Toronto: Oxford University Press

- Canada, 2004,p. 136/137, 241/242.

Revista Publicum

Rio de Janeiro, v.2, n. 2, 2016, p. 83-119

http://www.e-publicacoes.uerj.br/index.php/publicum

DOI: 10.12957/publicum.2016.22758 


\subsection{O processo legislativo comum}

No Canadá, faz-se uma distinção entre projetos de lei privados e públicos. Os primeiros são aqueles que afetam apenas um indivíduo ou pessoa jurídica. Já os projetos de lei públicos são os que afetam o público em geral ${ }^{80}$.

Os projetos de lei privados são introduzidos pelo Senado, onde são debatidos e refinados antes de sua discussão na Câmara dos Comuns. Já os projetos de lei públicos sofrem uma subdivisão: há os projetos de lei públicos governamentais (government bills) e os projetos de lei públicos parlamentares (private member's bills). A maior parte dos trabalhos parlamentares é dedicada aos projetos governamentais, de modo que os projetos de iniciativa dos parlamentares individuais geralmente não recebem muita atenção da Casa ${ }^{81}$. Segundo Monahan e Shaw, entre 1983 e 2003, apenas 37 (trinta e sete) projetos de lei parlamentares foram aprovados e, mesmo assim, todos deles com propósitos obscuros ou inócuos, na opinião dos autores ${ }^{82}$. Atualmente, segundo Kelly Blidook, que enxerga um aumento progressivo nas prerrogativas dos parlamentares individuais, a Câmara dos Comuns dedica cerca de 5 (cinco) horas por semana para debater moções e projetos propostos por backbenchers ${ }^{83}$.

Os projetos de lei governamentais são precedidos de uma notícia publicada 48 (quarenta e oito) horas antes de sua efetiva introdução no Parlamento, apresentando uma breve exposição de motivos. Os projetos governamentais podem ser introduzidos pela Câmara dos Comuns ou pelo Senado. No caso dos projetos relacionados a receitas e despesas (money bills), apenas a Câmara Baixa pode dar início ao processo legislativo, como já relatado ${ }^{84}$.

Os projetos de lei submetem-se a três rodadas de deliberação em cada Casa. A primeira rodada limita-se a à leitura e impressão do projeto, sem que seja possível debater ou emendar a proposta. Durante a segunda rodada, debatem-se os princípios do projeto, mas não suas disposições específicas. Nesta fase, também não se permitem emendas, mas os propósitos do projeto costumam ser efetivamente debatidos. Ainda na segunda fase, o projeto é enviado para um comitê parlamentar, que pode sugerir

80 MONAHAN, Patrick; SHAW, Byron. Constitutional Law. $4^{\text {th }}$ ed. Toronto: Irwin Law, 2013, p. 99.

${ }^{81} \mathrm{Em}$ sentido diverso, enfatizando a influência direta ou indireta causada pela atividade legiferante de parlamentares comuns, cf. BLIDOOK, Kelly. Exploring the role of 'legislators' in Canada: do members of Parliament influence policy? The Journal of Legislative Studies, v. 16, n. 1, March, 2010, p. 32-56.

82 MONAHAN, Patrick; SHAW, Byron. Constitutional Law. $4^{\text {th }}$ ed. Toronto: Irwin Law, 2013, p. 99.

${ }_{83}$ BLIDOOK, Kelly. Exploring the role of 'legislators' in Canada: do members of Parliament influence policy? The Journal of Legislative Studies, v. 16, n. 1, March, 2010, p. 36.

${ }^{84}$ MONAHAN, Patrick; SHAW, Byron. Constitutional Law. $4^{\text {th }}$ ed. Toronto: Irwin Law, 2013,p. 100. 
emendas à proposta. $\mathrm{O}$ comitê também redige um relatório sobre a matéria antes de enviá-la à consideração da Casa em sua composição plenária. A partir de então, os parlamentares podem apresentar suas próprias emendas ao projeto. Por fim, na terceira rodada, o projeto é votado pelo Plenário. Concluídas as três rodadas deliberativas, o projeto é encaminhado para a outra Casa, a fim de que o rito lá seja repetido. Após a fase parlamentar, o projeto é enviado ao Governador-geral, para que aponha a sanção real (royal assent) ao projeto. Somente então é que a lei ganha existência jurídica ${ }^{85}$.

Evidentemente, a descrição geral do procedimento legislativo, com suas diversas oportunidades para debate e emendas parlamentares, não deve ofuscar o fato de que, na prática, o governo consegue controlar o trâmite das propostas legislativas, conduzindo-as ao objetivo desejado. Os comitês parlamentares, por exemplo, têm seu papel de controle prejudicado pelo desumano volume de trabalho e pelo fato de que sua atuação começa apenas na segunda rodada, quando os elementos centrais dos projetos já foram discutidos e votados pelo Plenário. Desse modo, os comitês limitam-se a dispor sobre regras de menor importância ${ }^{86}$. Como se não bastasse, François Plante demonstra que o governo tem logrado contornar o obstrucionismo da oposição por meio de algumas standing orders (regras internas do Parlamento) capazes de acelerar o processo legislativo pela via da redução, muitas vezes drástica, do tempo dedicado ao debate parlamentar (curtailment of debate), impedindo-se a aposição de emendas indesejáveis, entre outros inconvenientes ${ }^{87}$.

\section{Os partidos políticos}

O Canadá, na contramão do que costuma ocorrer em sistemas políticos comparáveis, tradicionalmente reserva certo espaço para os chamados third parties, isto é, agremiações que se agregam ao esquema bipartidário típico da fórmula política britânica. De fato, mesmo se considerarmos que apenas dois partidos ocuparam o governo até hoje (Liberais e Conservadores, sob diferentes denominações), desde 1921 o sistema partidário canadense costuma abrigar de três a cinco partidos na arena parlamentar ${ }^{88}$.

${ }^{85}$ MONAHAN, Patrick; SHAW, Byron. Constitutional Law. $4^{\text {th }}$ ed. Toronto: Irwin Law, 2013,p. 100.

${ }^{86}$ DOCHERTY, David C. Parliament: Making the Case for Relevance. In: BICKERTON, James and GAGNON, Alain-G. Canadian Politics. Toronto: University of Toronto Press, 6th ed., 2014, p. 154, p. 163.

87 PLANTE, François. The Curtailment of Debate in the House of Commons. Canadian Parliamentary Review, vol. 36, no. 1, spring 2013, p. 28-36.

${ }_{88}$ BICKERTON, James. Competing for power. In: BICKERTON, James and GAGNON, Alain-G. Canadian Politics. Toronto: University of Toronto Press, $6^{\text {th }}$ ed., 2014, p. 257. 
Contudo, nem sempre foi assim. Conforme brevemente relatado na seção dedicada à história do governo de gabinete, o bipartidarismo à moda britânica foi a solução encontrada em 1867 para, de uma só vez, incrementar a eficiência do sistema político e acomodar o dualismo étnico entre os dois partidos dominantes, o Conservador e o Liberal $^{89}$.

Em 1921, ocorrem as primeiras eleições gerais após a Primeira Guerra. Nesse ano, os Liberais retornam ao poder, substituindo os Conservadores. A grande novidade, contudo, fica por conta da ascensão do novo Partido Progressista, forte no oeste do país e apoiado por um movimento populista, agrário e cético em relação à tradicional política partidária. O país presenciou ainda o surgimento de diversos candidatos trabalhistas independentes, que passaram a vocalizar os anseios da crescente classe operária. 0 certame eleitoral de 1921 foi o primeiro sinal de que o dualismo bipartidário já não conseguiria dar conta da crescente complexidade da sociedade canadense. Nos anos 30, com a Grande Depressão, o "populismo das pradarias" aumentaria sua expressão com o advento de dois novos partidos: a Federação Cooperativa da Commonwealth (CCF), de orientação socialista, e o Partido do Crédito Social, de perfil conservador, ambos com presença quase que exclusivamente regional. Mesmo diante dessa fragmentação partidária, contudo, os Liberais lograram estabelecer sua primazia no cenário político canadense, muito em função de sua habilidade para capturar os votos de Québec e para acomodar interesses de diferentes regiões, classes e grupos linguísticos ${ }^{90}$. No Canadá, essa prática de apelar a interesses heterogêneos, uma estratégia típica dos grandes partidos, denomina-se brokerage politics e ao longo da história tem sido utilizada igualmente pelos Conservadores, ainda que com menor sucesso ${ }^{91}$.

A hegemonia Liberal seria abalada em 1957, com a vitória do Partido Progressista Conservador, uma agremiação criada em 1942 a partir da fusão entre Conservadores e Progressistas. Seu líder, John Diefenbaker, representou o êxito da população anglófona concentrada em cidades pequenas e no grande território rural compreendido pelas províncias do oeste, a partir de Ontario. No entanto, Diefenbaker não duraria muito e logo cederia espaço ao Partido Liberal de Lester Pearson e, posteriormente, Pierre Trudeau, ambos partidários de uma política mais centrista, inclusiva e multicultural, que

89 BICKERTON, James. Competing for power. In: BICKERTON, James and GAGNON, Alain-G. Canadian Politics. Toronto: University of Toronto Press, $6^{\text {th }}$ ed., 2014, p. 250/251.

${ }^{90}$ BICKERTON, James. Competing for power. In: BICKERTON, James and GAGNON, Alain-G. Canadian Politics. Toronto: University of Toronto Press, $6^{\text {th }}$ ed., 2014, p. 250/251.

91 CARTY, Kenneth; CROSS, William. Political Parties and the Practice of Brokerage Politics. In: SMITH, David; COURTNEY, John (eds.). The Oxford Handbook of Canadian Politics. Toronto: Oxford University Press - Canada, 2010, p. 191-207.

Revista Publicum

Rio de Janeiro, v.2, n. 2, 2016, p. 83-119

http://www.e-publicacoes.uerj.br/index.php/publicum

DOI: 10.12957/publicum.2016.22758 
prevaleceria entre 1963 e 1984, com um breve intervalo Conservador em 1979. Nesta nova fase, o Novo Partido Democrata (NDP) firma-se como o "terceiro partido" por excelência, representando a descontente parcela mais à esquerda do espectro político ${ }^{92}$.

Em 1984, o Partido Progressista Conservador destrona o Partido Liberal, coroando os esforços de seu líder Brian Mulroney, um nativo de Québec, bilíngue, embora de origem irlandesa. Mulroney inovou ao tentar unir sob um mesmo manto duas tendências políticas díspares e aparentemente inconciliáveis: o eleitorado anglófono do oeste, tradicional base de apoio de seu partido, e o contingente francófono do Québec, com o qual conseguia lidar com certa naturalidade. Mulroney permaneceu por cerca de nove anos no poder, mas a incongruência de sua estratégia revelou-se evidente com o passar do tempo. Em 1993, sob o comando de sua sucessora, Kim Campbell, o Partido Progressista Conservador amargaria profunda derrota, cedendo o governo mais uma vez ao Partido Liberal, desta vez sob a batuta de Jean Chrétien ${ }^{93}$.

Até o fim de seu governo, em 2003, Chrétien deu continuidade à tradicional brokerage politics, mas o vácuo de poder causado pelo enfraquecimento dos Conservadores permitiu o advento de outros dois partidos regionais no cenário político: o Bloc Québecois, fruto da insatisfação dos francófonos com os rumos do país, e o Partido da Reforma (posteriormente "Aliança Canadense"), herdeiro da tradição populista do oeste anglófono, carente de representação expressiva por parte dos demais partidos (Liberal, Progressista Conservador e Novo Partido Democrata) ${ }^{94}$. Após o governo de Chrétien, o ex-ministro das finanças Paul Martin assumiria o bastão do Partido Liberal, mas não seria capaz de sustentar sua posição por muito tempo: em 2006, Martin perderia as eleições para Stephen Harper, líder do recém-criado Partido Conservador, resultado da fusão entre a Aliança Canadense e o moribundo Partido Progressista Conservador. Até a data de elaboração deste artigo (agosto de 2015), Harper permanece à frente do Governo.

O sistema partidário canadense, como se vê, encerra um aparente paradoxo: por um lado, os partidos atuam no Parlamento bem ao estilo de Westminster, com gabinete monopartidário e uma "Oposição Oficial" levada a cabo pelo maior partido não governista, como já visto; por outro lado, não há um bipartidarismo estrito e cada um dos

92 BICKERTON, James. Competing for power. In: BICKERTON, James and GAGNON, Alain-G. Canadian Politics. Toronto: University of Toronto Press, $6^{\text {th }}$ ed., 2014, p. 253.

93 BICKERTON, James. Competing for power. In: BICKERTON, James and GAGNON, Alain-G. Canadian Politics. Toronto: University of Toronto Press, $6^{\text {th }}$ ed., 2014, p. 256.

${ }^{94}$ BICKERTON, James. Competing for power. In: BICKERTON, James and GAGNON, Alain-G. Canadian Politics. Toronto: University of Toronto Press, $6^{\text {th }}$ ed., 2014, p. 256/257.

Revista Publicum

Rio de Janeiro, v.2, n. 2, 2016, p. 83-119

http://www.e-publicacoes.uerj.br/index.php/publicum

DOI: 10.12957/publicum.2016.22758 
partidos abrange um bloco mais ou menos heterogêneo de interesses étnicos e regionais, como ocorre nas democracias consensuais europeias ${ }^{95}$.

$\mathrm{Na}$ verdade, a recorrência dos third parties é meramente o reflexo de uma realidade social que não pode ser totalmente domada pelas características centralizadas do sistema parlamentar de Westminster, uma válvula de escape para os fortes regionalismos, que não encontram expressão na política nacional. O Senado, como visto, não é um representante legítimo dos interesses das províncias, revelando-se mero apêndice da política partidária que toma conta da própria Câmara dos Comuns. Curiosamente, o sistema majoritário distrital conhecido como first-past-the-post, cujo efeito principal é conferir primazia às maiores agremiações, acaba por garantir que partidos menores, porém com forte apoio regional, sejam favorecidos em seus distritos, o que catapulta seu sucesso nos governos provinciais e lhes garante algumas cadeiras no Parlamento. Mais do que a presença na Legislatura nacional, geralmente sufocada pelo governo de gabinete, é a tomada do poder nas províncias que se revela crucial para os partidos de nicho, os quais passam a entabular relações inter-federativas com o Primeiro Ministro em bases equânimes, pois no descentralizado federalismo canadense as províncias gozam de robusta autonomia ${ }^{96}$.

É inegável, portanto, que a política nacional sofre o impacto das questões regionais, ainda que não pela via do Parlamento: por um lado, o próprio Primeiro Ministro precisa assegurar para o seu partido uma ampla base de apoio regional, sob pena de não lograr êxito nas eleições seguintes (mote da tradicional brokerage politics); por outro, os governos provinciais tomados por third parties representam uma contínua e inevitável fonte de pressão sobre a agenda do governo nacional, a significar uma verdadeira “oposição federativa"97. Desse modo, os regionalismos acentuam-se principalmente na política intrapartidária, na competição eleitoral e no dito "federalismo executivo".

\section{As agências independentes}

95 BICKERTON, James. Competing for power. In: BICKERTON, James and GAGNON, Alain-G. Canadian Politics. Toronto: University of Toronto Press, $6^{\text {th }}$ ed., 2014, p. 274.

${ }_{96}$ BICKERTON, James. Competing for power. In: BICKERTON, James and GAGNON, Alain-G. Canadian Politics. Toronto: University of Toronto Press, 6 $6^{\text {th }}$ ed., 2014, p. 259.

${ }^{97}$ Como salienta KAISER, Andre. Parliamentary Opposition in Westminster Democracies: Britain, Canada, Australia and New Zealand. The Journal of Legislative Studies, v. 14, n. 1-2, 2008, p. 36, "federalism in Australia and Canada creates opportunities for opposition parties actually to govern on the sub-national level and use intergovernmental relations for influencing policy-making on the federal level". 
Idealmente, como visto, a democracia parlamentarista de Westminster pode ser caracterizada como um modelo "principal-agente" unilinear e hierarquizado. Ou, para usar a linguagem de Kaare Strøm, o parlamentarismo, aqui entendimento como sistema democrático-representativo, opera por meio de uma cadeia delegatória singular e indireta: singular, porque cada principal delega funções a somente um agente; indireta, porque o principal último (o povo) escolhe diretamente apenas seus representantes no Parlamento, mas não o primeiro ministro, os membros do gabinete e muito menos os servidores a eles subordinados ${ }^{98}$. A cadeia delegatória, por seu turno, é espelhada por uma cadeia de accountability igualmente singular e indireta, em sentido inverso: cada agente é responsável apenas perante seu único principal imediato e o povo, o principal último, exerce controle somente por meio das eleições, quando lhe é oportunizado punir ou recompensar os parlamentares, conforme o fracasso ou o êxito de seus mandatos ${ }^{99}$. Para usar uma descrição mais concreta: no governo de gabinete, os servidores respondem perante seus ministros; estes, perante o Parlamento e seus comitês, e os parlamentares, como um todo, perante o povo durante as eleições periódicas ${ }^{100}$. Sob outro prisma, isso revela que, durante o período interposto entre duas eleições, a accountability fica basicamente relegada à relação de confiança entre governo e Parlamento, com seus dispositivos políticos de mútuo controle, e ao ofício jurisdicional, este mais atuante na esfera dos direitos fundamentais entrincheirados na Constituição escrita.

Hoje, no entanto, essa descrição estilizada não traduz fielmente a realidade do sistema político canadense, que conta com série de agências independentes de controle, comumente designadas como "oficiais do Parlamento" (officers of Parliament). Tão marcante é a sua presença no Canadá que, para Richard Albert, o sistema político desse país já poderia receber a etiqueta do "parlamentarismo limitado" (constrained parlamentarianism) $)^{101}$.

No Canadá, os oficiais do Parlamento são burocratas legalmente investidos de autonomia técnica e administrativa para, com imparcialidade, exercer determinada função administrativa específica, geralmente (mas não exclusivamente) voltada ao

${ }_{98}$ STR $\varnothing \mathrm{M}$, Kaare. Parliamentary Democracy and Delegation. In: MULLER, Wolfgang; BERGMAN, Torbjorn; STR $\varnothing \mathrm{M}$, Kaare. (orgs.) Delegation and Accountability in Parliamentary Democracies. Oxford: Oxford University Press, 2003, p. 10.

${ }^{99}$ MULLER, Wolfgang; BERGMAN, Torbjorn; STR $\varnothing \mathrm{M}$, Kaare. Parliamentary Democracy: Promise and Problems. In: MULLER, Wolfgang; BERGMAN, Torbjorn; STR $\varnothing \mathrm{M}$, Kaare. (orgs.) Delegation and Accountability in Parliamentary Democracies. Oxford: Oxford University Press, 2003, p. 15.

100 THOMAS, Paul G. The past, present and future of officers of Parliament. Canadian Public Administration, v. 46, n. 3, 2003, p. 310.

101 ALBERT, Richard. The Fusion of Presidentialism and Parliamentarism. American JournalofComparative Law, v. 57, n. 3, p. 2009, p. 536-540.

Revista Publicum

Rio de Janeiro, v.2, n. 2, 2016, p. 83-119

http://www.e-publicacoes.uerj.br/index.php/publicum

DOI: 10.12957/publicum.2016.22758 
controle do governo ${ }^{102}$. Hoje, há oito oficiais do Parlamento. Destes, o mais tradicional e antigo é certamente o Auditor-geral, comparável (imperfeitamente) aos nossos Tribunais de Contas ${ }^{103}$.

Embora os oficiais do Parlamento não constituam propriamente uma novidade no cenário canadense (o cargo de Auditor-geral foi instituído em 1878, por exemplo), sua relevância vem alcançando patamares impensáveis duas décadas atrás, muito em função do ceticismo popular em relação à política tradicional, dos recorrentes escândalos de corrupção, do advento do chamado "novo gerencialismo" e, também, graças à ascensão de Stephen Harper, herdeiro dos ideias populistas do Partido da Reforma, que sempre enxergou o controle parlamentar com olhos de indisfarçada desconfiança ${ }^{104}$.

Em tese, como sugere o próprio nome que lhes é atribuído, a função básica dessas instituições é auxiliar o Parlamento em sua tarefa de fiscalização e controle do governo, incorporando, à Legislatura, a estrutura e a expertise técnica de que os parlamentares costumam carecer ${ }^{105}$. Para alguns, entretanto, é comum que esses burocratas independentes apresentem-se à opinião pública como entidades rigorosamente técnicas, atuantes acima da política, e capazes de revigorar a confiança do povo nas instituições estatais $^{106}$. Nessa linha, oficiais do Parlamento frequentemente replicam tarefas já desempenhadas por comissões parlamentares permanentes e, amiúde, reportam-se diretamente à mídia e ao público, não à Legislatura ${ }^{107}$. Assim, os officers of Parliament aportam um ingrediente adicional de complexidade ao já não tão simples arranjo parlamentarista canadense, na medida em que se interpõem como elementos estranhos entre Governo e Assembleia, esfumaçando a outrora linear cadeia de delegação e accountability construída entre aquelas instâncias políticas ${ }^{108}$. Sob outro prisma, a propalada independência dos officers of Parliament levanta uma questão fundamental na

102 Embora caracterizados como "czares" ou "watchdogs", certas agências não realizam tarefas de controle. Cf. CHAPLIN, Ann. The Constitutional Legitimacy of Officers of Parliament. National journal of constitutional law= Revue nationale de droit constitutionnel, v. 29, n. 1, 2011, p. 71-117.

${ }^{103}$ A função de Auditor-geral foi criada em 1878, aparentemente em resposta ao "escândalo do Pacífico", um conjunto de atos de corrupção relacionados ao desenvolvimento da ferrovia nacional. Cf. CHAPLIN, Ann. The Constitutional Legitimacy of Officers of Parliament. National journal of constitutional law= Revue nationale de droit constitutionnel, v. 29, n. 1, 2011, p. 76.

104 Nessa linha, v. SMITH, David. The People's House of Commons - theories of democracy in contention. Toronto: University of Toronto Press, 2007, p. 62-70.

105 THOMAS, Paul G. The past, present and future of officers of Parliament. Canadian Public Administration, v. 46, n. 3, 2003, p. 287.

106 SMITH, David. The People's House of Commons - theories of democracy in contention. Toronto: University of Toronto Press, 2007, p. 68.

107 CHAPLIN, Ann. The Constitutional Legitimacy of Officers of Parliament. National journal of constitutional law= Revue nationale de droit constitutionnel, v. 29, n. 1, 2011, p. 75/76, 86/87.

108 SMITH, David. The People's House of Commons - theories of democracy in contention. Toronto: University of Toronto Press, 2007, p. 64.

Revista Publicum

Rio de Janeiro, v.2, n. 2, 2016, p. 83-119

http://www.e-publicacoes.uerj.br/index.php/publicum

DOI: 10.12957/publicum.2016.22758 
teoria dos controles horizontais: quem vigia o vigia? Essa é uma pergunta ainda à procura de resposta, uma vez que o arsenal teórico sobre o parlamentarismo de Westminster não está bem equipado para a análise de instâncias burocráticas autônomas, que escapem ao esquema tradicional do princípio do governo responsável.

\section{Avaliação geral de síntese conclusiva}

Como visto ao longo deste artigo, o sistema de governo canadense adota os postulados básicos do parlamentarismo de Westminster: gabinetes monopartidários, predominância do Governo em relação ao Parlamento, primazia de dois partidos na arena parlamentar e sistema eleitoral majoritário distrital (o chamado first-past-the-post). De acordo com a nomenclatura de ArendLijphart ${ }^{109}$, é possível dizer que, ao menos na dimensão "executivo-partidos", o arranjo do Canadá possui tendência majoritária, não consensual. Nada obstante, trata-se uma tendência artificialmente induzida, como indicarei adiante.

No caso canadense, conforme ressaltado, a concentração do processo decisório no gabinete foi a resposta encontrada pelos framers do Ato Constitucional de 1867 para a histórica instabilidade política gerada pelo dualismo "França-Inglaterra", que costumava ser administrado por meio de governos de coalizão e de duplas maiorias no Parlamento ${ }^{110}$. Até aí, nada muito diferente do que ocorrera na própria Inglaterra, muito embora na metrópole as questões étnicas não tenham sido tão determinantes para a hipertrofia do gabinete ${ }^{111}$.

Apesar disso, o sistema exclusivamente bipartidário perdurou no Canadá somente até 1921. O período entre guerras aguçou os regionalismos e as desigualdades sociais, pavimentando o caminho para o advento de outros partidos, os third parties ou protest parties. A partir de então, o Canadá passou a abrigar no seio do Parlamento um conjunto de três a cinco partidos ${ }^{112}$. Contudo, os dois maiores partidos nunca deixaram de ser as referências centrais da política parlamentar canadense, uma herança de Westminster: o partido majoritário ocupa o todo-poderoso gabinete, ao passo que o segundo mais relevante exerce o papel de "Oposicão Oficial" (uma oposição com "O" maiúsculo, nas

109 LIJPHART, Arend. Patterns of Democracy. Patterns of democracy: Government forms and performance in thirty-six democracies. New Haven: Yale University Press, 1999, p. 3/4.

110 SMITH, David. Across the Aisle: Opposition in Canadian Politics. Toronto: University of Toronto Press, 2013, p. 29/30.

${ }^{111}$ COX, Gary W. The Efficient Secret: The Cabinet and the Development of Political Parties in Victorian England. Cambridge: Cambridge University Press, 1987.

112 BBICKERTON, James. Competing for power. In: BICKERTON, James and GAGNON, Alain-G. Canadian Politics. Toronto: University of Toronto Press, $6^{\text {th }}$ ed., 2014, p. 257. 
palavras de Allen Potter $\left.{ }^{113}\right)$. Aos demais partidos, a saída foi montar trincheiras nas províncias, locais de onde poderiam confrontar o Governo em pé de (quase) igualdade ${ }^{114}$. É evidente, portanto, que o consensualismo da dimensão federativa exerce algum impacto sobre a agenda governista, mas não a ponto de alterar a dinâmica binária, conflituosa e adversarial da política parlamentar.

De todo modo, o robusto federalismo canadense não é a única fonte de pressão sobre o Governo. A própria recorrência dos third parties cria um óbvio problema para o modelo de Westminster: a sombra dos governos minoritários. É claro que, quando possui status minoritário, o partido governista não pode gerir a máquina pública sem o auxílio das demais agremiações. É de se estranhar, no entanto, o modo como se dá essa colaboração: de maneira casuística, ad hoc, sem partilha do governo - a fórmula básica da ineficiência.

A ausência de coalizões pode ser explicada com base em um argumento familiar ao institucionalismo da escolha racional: os partidos não se engajam em coalizões porque conhecem a volatilidade do eleitorado canadense e do sistema first-past-the-post. Ou seja, apesar do moderado multipartidarismo observado no Canadá, a conquista do governo majoritário por uma única agremiação não é uma via de acesso proibido, como nos sistemas em que impera a representação proporcional ${ }^{115}$. Em algum momento, a insistência no governo monopartidário pode ser recompensada com o status majoritário, como demonstra a trajetória política do ex-Primeiro Ministro Stephen Harper, que lograria reverter a condição minoritária de seu governo após duas tentativas frustradas. De resto, nunca é demais relembrar a dependência da trajetória (path dependence): é natural que uma fórmula política aprovada pelo teste da história continue a ser replicada nos dias de hoje, talvez até sem maiores reflexões por parte dos atores políticos ${ }^{116}$.

113 A expressão foi colhida de KAISER, Andre. Parliamentary Opposition in Westminster Democracies: Britain, Canada, Australia and New Zealand. The Journal of Legislative Studies, v. 14, n. 1-2, 2008, p. 23.

114 BICKERTON, James. Competing for power. In: BICKERTON, James and GAGNON, Alain-G. Canadian Politics. Toronto: University of Toronto Press, $6^{\text {th }}$ ed., 2014, p. 259.

115 CODY, Howard. Minority Government in Canada: The Stephen Harper Experience. American Review of Canadian Studies, v. 38, n. 1, 2008, p. 31.

${ }^{116}$ A expressão "path dependence", nas palavras de Mariana Prado e Michael Trebilcock, "descreve como o reforço de um determinado conjunto de arranjos ao longo do tempo aumenta o custo de sua mudança" . Isto é, a ideia de "path dependence" enfatiza que toda escolha institucional produz consequências não planejadas e os custos de sua reversão superveniente podem ser muito altos, inviabilizando reformas extremas. Vale dizer: sob determinadas circunstâncias, certa escolha institucional pode gerar um estado de coisas que futuros reformadores não conseguirão alterar facilmente por vontade própria, ainda que os resultados produzidos pela estrutura existente sejam subótimos. Em tal cenário, mudanças profundas seriam possíveis, mas dependeriam necessariamente de "conjunturas críticas". Sobre o conceito aqui descrito, cf. PRADO, Mariana; 
A grande incógnita fica por conta dos officers of Parliament. Seriam esses burocratas capazes de alterar o balanço entre eficiência e controle no arranjo político canadense? Pessoalmente, entendo que sim, mas não sentido mais óbvio, geralmente salientado pelos analistas.

Em geral, como ressaltei anteriormente, diz-se que os officers of Parliament aumentam o grau de controle exercido sobre as atividades governamentais, seja por recursos próprios, seja pelo fortalecimento da Legislatura ${ }^{117}$. Na verdade, penso eu, essas estruturas burocráticas geram efeito diametralmente oposto: tendem a fortalecer o Governo.

Por um lado, o fortalecimento do Governo dá-se pela fragilização do Parlamento, que passa a dividir suas tarefas com autoridades burocráticas que se vendem ao povo e à imprensa como porta-vozes assépticos da técnica e da moralidade pública, os únicos capazes de recuperar a confiança popular no Estado ${ }^{118}$. Nessa linha, é comum que burocratas independentes até mesmo censurem o trabalho de comissões parlamentares. $\mathrm{E}$, de fato, o volume de trabalho gerado pela atividade governamental e as recorrentes interrupções no processo legislativo fazem com que os membros do Parlamento tornemse reféns dos relatórios confeccionados pelos oficiais ${ }^{119}$. Em suma: para os parlamentares comuns, o quadro que já era ruim na era clássica do governo de gabinete torna-se ainda pior com a ascensão dos burocratas independentes.

Por outro lado, parece falaciosa a impressão de que o controle burocrático cause muitos constrangimentos ao Governo. É claro que nenhum Governo convive bem com a ideia de ser controlado. Igualmente, a julgar pelo relato de Ann Chaplin, é de se esperar que os oficiais do Parlamento conduzam seu trabalho de maneira séria e comprometida ${ }^{120}$. Apesar disso, por que a atuação desses oficiais seria relativamente benigna em relação ao Governo?

Várias explicações poderiam ser avançadas. Uma delas diz respeito ao fato de que o Governo tende a perseguir a satisfação de interesses globais. Isso ocorre, não apenas em virtude de sua missão institucional precípua, de caráter executivo, mas principalmente

TREBILCOCK, Michael. Path dependence, development, and the dynamics of institutional reform. University of Toronto Law Journal, v. 59, n. 3, 2009, p 341-379.

117 THOMAS, Paul G. The past, present and future of officers of Parliament. Canadian Public Administration, v. 46, n. 3, 2003, p. 288.

118 SMITH, David. The People's House of Commons - theories of democracy in contention. Toronto: University of Toronto Press, 2007, p. 68.

${ }^{119}$ CHAPLIN, Ann. The Constitutional Legitimacy of Officers of Parliament. National journal of constitutional law= Revue nationale de droit constitutionnel, v. 29, n. 1, 2011, p. 85.

${ }^{120}$ CHAPLIN, Ann. The Constitutional Legitimacy of Officers of Parliament. National journal of constitutional law= Revue nationale de droit constitutionnel, v. 29, n. 1, 2011, p. 72. 
em razão das demandas de seu eleitorado, que se confunde com a nação como um todo. Quando a economia sofre ou quando algum novo escândalo de corrupção vem à tona, presidentes ou premiers que levam a culpa ${ }^{121}$. Assim, o Primeiro Ministro é o maior interessado em assegurar o controle sobre a máquina pública, de modo a contornar os "problemas de agência" que possam colocar em risco a implementação de seu mandato popular ${ }^{122}$. Nesse contexto, é evidente que o trabalho dos officers of Parliament serve de double check em relação a políticas públicas já monitoradas por órgãos de controle interno ao Governo, aumentando, assim, a qualidade da atuação governamental e, por conseguinte, a popularidade do Primeiro Ministro. Naturalmente, a relação entre Governo e oficiais do Parlamento pode gerar tensões, já que as autoridades independentes publicizam erros que, de outro modo, seriam sanados internamente sem grande alarde ${ }^{123}$. Não custa ressaltar, no entanto, que os Officers of Paliament nada podem fazer sozinhos no contexto canadense, pois não possuem a competência repressora atribuída a muitos de seus primos presidencialistas, como os Tribunais de Contas brasileiros. Além disso, essas tensões são facilmente contornadas em períodos majoritários, quando a oposição é praticamente incapaz de pressionar o Governo com os recursos parlamentares.

Como se não bastasse, eventuais excessos burocráticos podem ser podados pelo primeiro ministro, caso deseje. Conforme salientado por George Tsebelis ${ }^{124}$, um arranjo político dotado de poucos atores com poder de veto tende a ser menos hostil à mudança do status quo legislativo. Em outras palavras: quanto menor o número de atores com poder de veto, mais fácil torna-se alterar a legislação vigente. Sistemas majoritários ou eficientes, como o canadense, claramente possuem poucos atores com poder de veto: para aprovar um projeto de lei, o Primeiro Ministro precisa contar basicamente com os votos de seus correligionários, que atuam em bloco. Em geral, a Câmara dos Comuns, o Senado e a rainha nada podem fazer contra a aprovação dos projetos de lei governamentais. O fato, então, é que nenhum direito ou prerrogativa entrincheirado em lei ordinária é capaz de resistir à força do primeiro ministro: em regra, se considerarmos apenas os aspectos institucionais da política parlamentar, o Governo pode fazer tábula

121 MOE, Terry M.; CALDWELL, Michael. The institutional foundations of democratic government: A comparison of presidential and parliamentary systems. Journal of Institutional and Theoretical Economics (JITE)/Zeitschriftfür die gesamte Staatswissenschaft, 1994, p. 175/176.

122 Sobre os "problemas de agência", cf. STR ØM, Kaare. Parliamentary Democracy and Delegation. In: MULLER, Wolfgang; BERGMAN, Torbjorn; STR $\varnothing \mathrm{M}$, Kaare. (orgs.) Delegation and Accountability in Parliamentary Democracies. Oxford: Oxford University Press, 2003.

${ }_{123}$ GOOD, David. The Politics of Public Money. $2^{\text {nd }}$ ed. Toronto: University of Toronto Press, 2014, p. 118-143.

124 TSEBELIS, George. Veto Players: How political institutions work. Princeton: Princeton University Press, 2002, passim. 
rasa de qualquer prerrogativa assegurada em lei aos officers of Parliament. Isto é: a decantada autonomia burocrática, porque estribada apenas em lei ordinária, pode ser desfeita a qualquer tempo. Sendo assim, sua perenidade pressupõe autorrestrição por parte do Governo ${ }^{125}$. Uma autorrestrição que, no mais das vezes, dependerá de seu cálculo eleitoral e da credibilidade construída pela agência independente ao longo do tempo.

O perfil majoritário do sistema de governo canadense é por vezes reforçado com a invocação exagerada de convenções não escritas por parte da Administração Pública. Na prática, tem sido observado, por exemplo, que departamentos governamentais recusamse a colaborar com os oficiais do Parlamento sob a alegação de que seus respectivos Ministros devem prestar contas não a burocratas autônomos, mas ao Parlamento eleito (princípio da responsabilidade ministerial) ${ }^{126}$. Ocorre que a Legislatura tampouco é capaz de exercer de forma eficaz sua função de controle, dada a dinâmica da política partidária. Por fim, o próprio Judiciário, que poderia exercer um papel ativo no controle dos atos administrativos, nem sempre parece disposto arbitrar conflitos entre os Poderes ${ }^{127}$. Nesse contexto, o Governo vê-se livre de amarras dignas de nota.

Resta saber se essa dinâmica majoritária ou eficiente é profundamente alterada no cenário de "governo minoritário", quando os atores partidários da oposição ganham importância. É de se esperar, com base em Tsebelis, que o status minoritário não seja um obstáculo intransponível à eficiência do parlamentarismo de Westminster, pois ao governante sempre será possível moderar sua agenda e, no limite, empregar recursos institucionais suficientes para forçar as políticas que lhe pareçam desejáveis ${ }^{128}$. Todavia, ao contrário do que parece postular o estudioso, a gestão de governos minoritários pode não ser tão simples, como sugerem os governos de Stephen Harper entre 2006 e 2011, quando a oposição parlamentar conseguiu forçá-lo a retroceder em momentos políticos cruciais. Mas essa é uma história a ser contada em outra ocasião.

$125 \mathrm{Em}$ linha semelhante, MOE, Terry M.; CALDWELL, Michael. The institutional foundations of democratic government: A comparison of presidential and parliamentary systems. Journal of Institutional and Theoretical Economics (JITE)/Zeitschriftfür die gesamte Staatswissenschaft, 1994, p. 171-195.

126 SMITH, David. Across the Aisle: Opposition in Canadian Politics. Toronto: University of Toronto Press, 2013, p. 117.

127JORDAO, Eduardo Ferreira; ROSE-ACKERMAN, Susan. Judicial Review of Executive Policymaking in Advanced Democracies: Beyond Rights Review. Administrative Law Review, 2014, p. 1-72.

128 TSEBELIS, George. Veto Players: How political institutions work. Princeton: Princeton University Press, 2002,p. 99-103. 


\section{Referências Bibliográficas}

ALBERT, Richard. The Fusion of Presidentialism and Parliamentarism. American Journal of Comparative Law, v. 57, n. 3, 2009, p. 531-577.

BARROSO, Luís Roberto. Curso de Direito Constitucional Contemporâneo. São Paulo: Saraiva, 2009.

BICKERTON, James. Competing for power. In: BICKERTON, James and GAGNON, Alain-G. Canadian Politics. 6th ed. Toronto: University of Toronto Press, 2014, p. 249-280.

BLIDOOK, Kelly. Exploring the role of 'legislators' in Canada: do members of Parliament influence policy? The Journal of Legislative Studies, v. 16, n. 1, March, 2010, p. 32-56.

BROOKS, Stephen. Canadian Democracy: An Introduction. 4th ed. Toronto: Oxford University Press - Canada, 2004.

CARTY, Kenneth; CROSS, William. Political Parties and the Practice of Brokerage Politics. In: SMITH, David; COURTNEY, John (eds.). The Oxford Handbook of Canadian Politics. Toronto: Oxford University Press - Canada, 2010, p. 191-207.

CHAPLIN, Ann. The Constitutional Legitimacy of Officers of Parliament. National journal of constitutional law= Revue nationale de droit constitutionnel, v. 29, n. 1, 2011, p. 71-117.

CODY, Howard. Minority Government in Canada: The Stephen Harper Experience. American Review of Canadian Studies, v. 38, n. 1, 2008, p. 27-42.

COX, Gary W. The Efficient Secret: The Cabinet and the Development of Political Parties in Victorian England. Cambridge: Cambridge University Press, 1987.

DOCHERTY, David C. Parliament: Making the Case for Relevance. In: BICKERTON, James and GAGNON, Alain-G. Canadian Politics. Toronto: University of Toronto Press, 6 th ed., 2014, p. 154.

GOOD, David. The Politics of Public Money. 2nd ed. Toronto: University of Toronto Press, 2014, p. 118-143.

HELMS, Ludger. Five ways of institutionalizing political opposition: lessons from the advanced democracies. Government and Opposition, v. 39, n. 1, 2004, p. 22-54.

HODGINS, Bruce; WRIGHT, Don; HEICK, Welf. Federalism in Canada and Australia: The early years. Wilfrid Laurier Univ. Press, 2010.

HOGG, Peter. Constitutional Law of Canada. Toronto: Carswell, 2014.

JORDAO, Eduardo Ferreira; ROSE-ACKERMAN, Susan. Judicial Review of Executive Policymaking in Advanced Democracies: Beyond Rights Review. Administrative Law Review, 2014, p. 1-72.

KAISER, Andre. Parliamentary Opposition in Westminster Democracies: Britain, Canada, Australia and New Zealand. The Journal of Legislative Studies, v. 14, n. 1-2, 2008, p. 20-45. 
LEVY, Gary. A Crisis Not Made in a Day. In: RUSSELL, P. and SOSSIN, L. (eds.). Parliamentary Democracy in Crisis. Toronto: University of Toronto Press, 2009, p. 19-29.

LIJPHART, Arend. Patterns of Democracy. Patterns of democracy: Government forms and performance in thirty-six democracies. New Haven: Yale University Press, 1999.

MCMENEMY, John. The Language of Canadian Politics - a guide to important terms \& concepts. 4th ed. Wilfrid Laurier University Press, 2006, p. 10.

MOE, Terry M.; CALDWELL, Michael. The institutional foundations of democratic government: A comparison of presidential and parliamentary systems. Journal of Institutional and Theoretical Economics (JITE)/Zeitschriftfür die gesamteStaatswissenschaft, 1994, p. 171-195.

MÖLLERS, Christoph. The Three Branches - A Comparative Model of Separation of Powers. Oxford: Oxford University Press, 2013.

MONAHAN, Patrick; SHAW, Byron. Constitutional Law. 4th ed. Toronto: Irwin Law, 2013, p. 14.

MULLER, Wolfgang; BERGMAN, Torbjorn; STR $\varnothing \mathrm{M}$, Kaare. Parliamentary Democracy: Promise and Problems. In: MULLER, Wolfgang; BERGMAN, Torbjorn; STR ØM, Kaare. (orgs.) Delegation and Accountability in Parliamentary Democracies. Oxford: Oxford University Press, 2003.

PLANTE, François. The Curtailment of Debate in the House of Commons. Canadian Parliamentary Review, vol. 36, no. 1, spring 2013, p. 28-36.

PRADO, Mariana; TREBILCOCK, Michael. Path dependence, development, and the dynamics of institutional reform. University of Toronto Law Journal, v. 59, n. 3, 2009, p 341-379.

RUSSELL, Peter. Learning to Live with Minority Parliaments. In: RUSSELL, P. and SOSSIN, L. (eds.). Parliamentary Democracy in Crisis. Toronto: University of Toronto Press, 2009, p. 136-149.

SARMENTO, Daniel; SOUZA NETO, Cláudio Pereira de. Direito Constitucional - teoria, história e métodos de trabalho. Belo Horizonte: Fórum, 2012.

SAVOIE, Donald J. Power at the Apex: Executive Dominance. In: BICKERTON, James and GAGNON, Alain-G. Canadian Politics. Toronto: University of Toronto Press, 6 th ed., 2014, p. 135.

SMITH, David. Across the Aisle: Opposition in Canadian Politics. Toronto: University of Toronto Press, 2013, p. 29/30.

The People's House of Commons - theories of democracy in contention. Toronto: University of Toronto Press, 2007.

STR $\varnothing \mathrm{M}$, Kaare. Parliamentary Democracy and Delegation. In: MULLER, Wolfgang; BERGMAN, Torbjorn; STR ØM, Kaare. (orgs.) Delegation and Accountability in Parliamentary Democracies. Oxford: Oxford University Press, 2003. 
TAVARES, André Ramos. Curso de Direito Constitucional. 10ạ ed. São Paulo: Saraiva, p. 44.

THOMAS, Paul G. The past, present and future of officers of Parliament. Canadian Public Administration, v. 46, n. 3, 2003, p. 287-314.

TSEBELIS, George. Veto Players: How political institutions work. Princeton: Princeton U (EDIÇÃO / ANO)

\section{Recebido em 12/05/2016}

\section{Aceito em 27/11/2016}

